BNL-114140-2017-JA

\title{
Operando Synchrotron XRD Investigation of Silver Metal Formation upon Electrochemical Reduction of Silver Iron Pyrophosphate (Ag7Fe3(P2O7)4)
}

\author{
Y. Zhang, K. C. Kirshenbaum, \\ A. C. Marschilok, E. S. Takeuchi, and K. J. Takeuchi
}

Submitted to Journal of Physical Chemistry C

June 8, 2017

Energy and Photon Sciences Directorate

Brookhaven National Laboratory

\author{
U.S. Department of Energy \\ USDOE Office of Science (SC), \\ Basic Energy Sciences (BES) (SC-22)
}

\begin{abstract}
Notice: This manuscript has been co-authored by employees of Brookhaven Science Associates, LLC under Contract No. DE-SC0012704 with the U.S. Department of Energy. The publisher by accepting the manuscript for publication acknowledges that the United States Government retains a non-exclusive, paid-up, irrevocable, world-wide license to publish or reproduce the published form of this manuscript, or allow others to do so, for United States Government purposes.
\end{abstract}




\section{DISCLAIMER}

This report was prepared as an account of work sponsored by an agency of the United States Government. Neither the United States Government nor any agency thereof, nor any of their employees, nor any of their contractors, subcontractors, or their employees, makes any warranty, express or implied, or assumes any legal liability or responsibility for the accuracy, completeness, or any third party's use or the results of such use of any information, apparatus, product, or process disclosed, or represents that its use would not infringe privately owned rights. Reference herein to any specific commercial product, process, or service by trade name, trademark, manufacturer, or otherwise, does not necessarily constitute or imply its endorsement, recommendation, or favoring by the United States Government or any agency thereof or its contractors or subcontractors. The views and opinions of authors expressed herein do not necessarily state or reflect those of the United States Government or any agency thereof. 


\section{Operando Synchrotron XRD Investigation of Silver}

\section{Metal Formation upon Electrochemical Reduction of}

\section{Silver Iron Pyrophosphate $\left(\mathrm{Ag}_{7} \mathrm{Fe}_{3}\left(\mathrm{P}_{2} \mathrm{O}_{7}\right)_{4}\right)$}

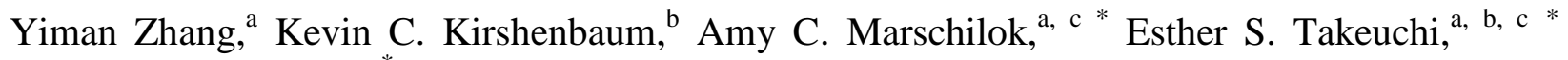
Kenneth J. Takeuchi ${ }^{\text {a, c * }}$

a Department of Chemistry, Stony Brook University, Stony Brook, NY 11794

b Energy Sciences Directorate, Brookhaven National Laboratory, Upton, NY 11973

c Department of Materials Science and Chemical Engineering, Stony Brook University, Stony Brook, NY 11794 
ABSTRACT: The formation of conductive metallic silver upon electrochemical reduction and lithiation of $\mathrm{Ag}_{7} \mathrm{Fe}_{3}\left(\mathrm{P}_{2} \mathrm{O}_{7}\right)_{4}$ is investigated. Alternating current impedance spectroscopy measurements show a 34\% decrease in charge transfer resistance upon one electron equivalent (ee) of reduction, which is coincident with the formation of a Ag metal conductive network evidenced by both ex-situ and operando x-ray diffraction. Quantitative assessment of Ag metal formation derived from operando XRD shows that only $\mathrm{Ag}^{+}$ions are reduced during the first 3ee, followed by simultaneous reduction of $\mathrm{Ag}^{+}$and $\mathrm{Fe}^{3+}$ reduction for the next 5ee (3ee to 8ee), culminating in reduction of the remaining $\mathrm{Ag}^{+}$. Scanning electron microscopy images show smaller Ag metal crystallite size and shorter nearest neighbor distance between and among Ag particles with higher depth of discharge. A high rate intermittent pulsatile discharge test is conducted where the cell delivered 12 total pulses during full discharge to probe the effect of $\mathrm{Ag}$ metal formation on the $\mathrm{Li} / \mathrm{Ag}_{7} \mathrm{Fe}_{3}\left(\mathrm{P}_{2} \mathrm{O}_{7}\right)_{4}$ cell electrochemistry. The Ohmic resistance is derived from the voltage drop of each pulse. The resistance is $65 \mathrm{Ohm}$ initially, reaches its minimum 26 Ohm at 4.5 ee discharge and levels off at $35 \mathrm{Ohm}$ after 7.0 ee reduction. The initial Ag reduction is more significant for the conductive network formation indicated by the decrease of both $\mathrm{R}_{c t}$ and ohmic resistance, which facilitates the high power output of the cell. 


\section{Introduction}

Compared to oxide cathode materials, polyanion cathodes can offer improved stability and avoid oxygen evolution during cycling. ${ }^{1}$ Among the polyanion framework materials, (e.g. $\mathrm{PO}_{4}{ }^{2}, \mathrm{P}_{2} \mathrm{O}_{7}{ }^{3-}$ $\left.{ }^{7}, \mathrm{XO}_{4}(\mathrm{X}=\mathrm{Fe}, \mathrm{Mo} \text { and } \mathrm{W})^{8}, \mathrm{SiO}_{4}{ }^{9}, \mathrm{PO}_{4} \mathrm{~F}^{10}\right)$, the phosphates have been a material class of particular interest since the commercialization of $\mathrm{LiFePO}_{4}{ }^{2,11}$. However, the inherently low electrical conductivity of the $\mathrm{LiFePO}_{4}$ material ${ }^{2}$ has been a barrier to full realization of its theoretical capacity at high rate. Significant work has been done to modify the $\mathrm{LiFePO}_{4}$ material to improve its electrical conductivity, including size reduction and intimately mixing the material with carbon. Nanocomposites of $\mathrm{LiFePO}_{4}$ and conductive carbon were prepared by using carbon xerogel from formaldehyde and surface-oxidized carbon. Both synthetic methods resulted in $\mathrm{LiFePO}_{4} / \mathrm{C}$ composite which achieved 90\% theoretical capacity at $\mathrm{C} / 2$ and $70 \%$ capacity at 5C. ${ }^{12}$ Nanoscale $\mathrm{LiFePO}_{4}$ powder with high crystallinity synthesized in a Polyol medium delivered $50 \mathrm{mAh} / \mathrm{g}$ capacity at $60^{\circ} \mathrm{C} .{ }^{13}$ While such approaches have markedly improved the functional capacity of the material, they complicate the synthesis which can prohibit scale up and commercialization.

Pyrophosphate materials often exhibit similar low electrical conductivity with that of phosphate materials since their metal $(\mathrm{M})$ polyhedrons are bridged by phosphate groups $\left(\mathrm{PO}_{4}{ }^{3-}\right)$ with no direct M-O-M bond. ${ }^{11,14}$ However, the open framework provides the opportunity for relatively high ionic diffusion in the solid which can enhance the rate capability for ion transport. An illustrative example in this regard is the $\mathrm{A}_{2} \mathrm{MP}_{2} \mathrm{O}_{7}(\mathrm{~A}=\mathrm{Li}, \mathrm{Na}$ and $\mathrm{M}=\mathrm{Fe}, \mathrm{Mn}, \mathrm{Co})$ family of materials. $\mathrm{Na}_{2} \mathrm{FeP}_{2} \mathrm{O}_{7}$ delivered two thirds of its theoretical capacity in a sodium ion battery at $1 \mathrm{C}$ without nanosizing or carbon coating. ${ }^{15}$ The antisite defect structure in $\mathrm{Na}_{2} \mathrm{MP}_{2} \mathrm{O}_{7}(\mathrm{M}=\mathrm{Fe}$, $\mathrm{Mn}$ ) results in low activation energy for long-range three-dimensional Na-ion diffusion, 
contributing favorably to its high rate capability. ${ }^{3,16-18} \mathrm{Na}_{7} \mathrm{Fe}_{3}\left(\mathrm{P}_{2} \mathrm{O}_{7}\right)_{4}$ has also been reported to be a fast ionic conductor on the order of $10^{-6} \mathrm{~S} / \mathrm{cm}$ at $100{ }^{\circ} \mathrm{C}$ with two dimensional diffusion pathways in the $\pi 2$ plane formed by the phosphate group..$^{19}$ Thus, the identification of materials with structures analogous to the $\mathrm{Na}_{7} \mathrm{Fe}_{3}\left(\mathrm{P}_{2} \mathrm{O}_{7}\right)_{4}$ framework could potentially result in battery electrodes with high rate capability.

Designing materials that generate conductive $\mathrm{Ag}^{0}$ metal in-situ upon electrochemical discharge through reduction-displacement of $\mathrm{Ag}^{+}$from the parent polyanion framework structure is a strategy to enhance the electrical conductivity via formation of a conducting network which promotes full active material utilization. ${ }^{20-21}$ This concept has been successfully applied to several members of the silver vanadium phosphorous oxide $\left(\mathrm{Ag}_{\mathrm{w}} \mathrm{V}_{\mathrm{x}} \mathrm{P}_{\mathrm{y}} \mathrm{O}_{\mathrm{z}}\right)$ family of cathode materials in Li based batteries, ${ }^{22-25}$ and is relevant to structurally related materials such as $\mathrm{Ag}_{2} \mathrm{~V}_{4} \mathrm{O}_{11}$ and other silver vanadium oxides, ${ }^{26-28} \mathrm{Ag}_{4} \mathrm{~V}_{2} \mathrm{O}_{6} \mathrm{~F}_{2}{ }^{29}$ and $\beta-\mathrm{Ag}_{0.33} \mathrm{~V}_{2} \mathrm{O}_{5}{ }^{30}$ In the phosphate based $\mathrm{Ag}_{2} \mathrm{VO}_{2} \mathrm{PO}_{4}$ material, the formation of silver nanoparticles upon initial electrochemical reduction results in a 15,000 fold decreases. ${ }^{21}$ More recent work discharging $\mathrm{Ag}_{2} \mathrm{VO}_{2} \mathrm{PO}_{4}$ single particles illustrated that Ag metal formation upon initial discharge could affect both inter-and intra-particle conductivities. ${ }^{31}$ The silver vanadium diphosphate, $\mathrm{Ag}_{2} \mathrm{VP}_{2} \mathrm{O}_{8}$ also demonstrated a significant increase in conductivity via in-situ formation of silver metal nanoparticles ${ }^{25}$.

$\mathrm{Ag}_{7} \mathrm{Fe}_{3}\left(\mathrm{P}_{2} \mathrm{O}_{7}\right)_{4}$, a material analogous in structure to $\mathrm{Na}_{7} \mathrm{Fe}_{3}\left(\mathrm{P}_{2} \mathrm{O}_{7}\right)_{4}$, but with $\mathrm{Ag}^{+}$substituted, was hypothesized to have both excellent electrical and ionic conductivity. We verified that $\mathrm{Ag}_{7} \mathrm{Fe}_{3}\left(\mathrm{P}_{2} \mathrm{O}_{7}\right)_{4}$ functions well as the cathode material in Li based batteries with high rate capability, delivering six electrons at the rate of $\mathrm{C} / 2.5$ in the first discharge. ${ }^{32}$ In addition, the 
$\mathrm{Fe}^{3+} / \mathrm{Fe}^{2+}$ redox couple shows good reversibility and excellent rate capability with $66 \%$ capacity retention when current density increased from $64 \mathrm{~mA} / \mathrm{g}$ to $256 \mathrm{~mA} / \mathrm{g}$.

Operando synchrotron based XRD techniques have been intensively applied in a variety of battery related research, including investigations related to the $\mathrm{Li}-\mathrm{S}^{33-35}, \mathrm{Li} / \mathrm{Na}-\mathrm{O}_{2}{ }^{36}$, $\mathrm{LiFePO}_{4} / \mathrm{FePO}_{4}$ systems ${ }^{37-40}, \mathrm{AB}_{2} \mathrm{O}_{4}(\mathrm{~A}, \mathrm{~B}=$ transition metal, e.g $\cdot \mathrm{A}=\mathrm{Co}, \mathrm{B}=\mathrm{Fe}, \mathrm{Mn})$ spinel anode material $^{41-43}$ or anatase ${ }^{44-45}$ in Li ion battery, and Zn-Ni aqueous secondary battery ${ }^{46}$. Notably, transmission synchrotron XRD geometry is widely employed due to convenient set up. $^{35,47-48}$ Compared to ex-situ measurements, in-situ and operando techniques can provide direct information on the system in a non-equilibrium state, allowing a truer visualization of what is happening during the electrochemical reduction and oxidation processes. For example, the metastable phase of $\mathrm{Li}_{x} \mathrm{FePO}_{4}$ under electrochemical phase transition has been directly observed with this techique. ${ }^{38}$ Our prior studies on the $\mathrm{Ag}_{\mathrm{w}} \mathrm{V}_{\mathrm{x}} \mathrm{P}_{\mathrm{y}} \mathrm{O}_{\mathrm{z}}$ family materials via in-situ energy dispersive X-ray diffraction (EDXRD) method have demonstrated the ability to follow the reduction-displacement process through Ag metal network formation in the electrode and provides opportunity to study the effect of the conductive network structure on the electrochemistry of the electrode. ${ }^{49-51}$

In this paper, we monitor the formation of conductive Ag metal as a function of discharge in an $\mathrm{Ag}_{7} \mathrm{Fe}_{3}\left(\mathrm{P}_{2} \mathrm{O}_{7}\right)_{4}$ electrode using a combination of ex-situ and operando measurements. In contrast to the prior energy dispersive XRD method used to understand the silver reduction-displacement process, a monochromatic angle dispersed XRD measurement is used here. The first operando transmission synchrotron XRD measurements tracking $\mathrm{Ag}^{0}$ formation operando during a reduction-displacement and insertion reactions is conducted. The resulting two dimensional Ag metal formations are visualized using ex-situ scanning electron microscopy (SEM). AC 
impedance spectroscopy is applied to determine the change in charge transfer resistance $\left(\mathrm{R}_{c t}\right)$ during the early stage of electrochemical reduction for lithium/silver iron pyrophosphate, $\mathrm{Li} / \mathrm{Ag}_{7} \mathrm{Fe}_{3}\left(\mathrm{P}_{2} \mathrm{O}_{7}\right)_{4}$ electrochemical cells. An intermittent $10 \mathrm{~mA} / \mathrm{cm}^{2}$ current pulse test is used to study the impact of Ag metal formation on the ohmic resistance of $\mathrm{Li} / \mathrm{Ag}_{7} \mathrm{Fe}_{3}\left(\mathrm{P}_{2} \mathrm{O}_{7}\right)_{4}$ cells under conditions demanding high power output.

\section{Experimental details}

\section{Synthesis and characterization}

$\mathrm{Ag}_{7} \mathrm{Fe}_{3}\left(\mathrm{P}_{2} \mathrm{O}_{7}\right)_{4}$ was synthesized by ion exchange from $\mathrm{Na}_{7} \mathrm{Fe}_{3}\left(\mathrm{P}_{2} \mathrm{O}_{7}\right)_{4}$ and $\mathrm{AgNO}_{3}$ at $250^{\circ} \mathrm{C}$. $\mathrm{Na}_{7} \mathrm{Fe}_{3}\left(\mathrm{P}_{2} \mathrm{O}_{7}\right)_{4}$ material was synthesized via a solid state reaction using a modification of a previously reported method. ${ }^{52-53}$ Briefly, $\mathrm{Na}_{4} \mathrm{P}_{2} \mathrm{O}_{7}, \mathrm{Fe}\left(\mathrm{NO}_{3}\right)_{3} \cdot 9 \mathrm{H}_{2} \mathrm{O}$, and $\mathrm{P}_{2} \mathrm{O}_{5}$ were mixed at room temperature and heated to $550^{\circ} \mathrm{C}$. After cooling, the sample was washed with deionized water and dried in a vacuum oven. Room temperature x-ray diffraction data for the $\mathrm{Ag}_{7} \mathrm{Fe}_{3}\left(\mathrm{P}_{2} \mathrm{O}_{7}\right)_{4}$ products were collected using a Rigaku SmartLab diffractometer with $\mathrm{Cu}-\mathrm{K} \alpha$ radiation in Bragg Brentano geometry with a $\mathrm{D} /$ tex detector and a $\mathrm{K}_{\beta}$ filter. Inductively coupled plasma optical emission spectroscopy (ICP-OES) was performed using a ThermoScientific iCap 6000 ICP spectrometer. Scanning electron microscopy (SEM) images were obtained using a JSM-6010Plus instrument at $10 \mathrm{kV}$ voltage with low vacuum mode. Analysis of the SEM images was conducted using Image software ${ }^{54}$.

\section{Electrochemical testing}

$\mathrm{Ag}_{7} \mathrm{Fe}_{3}\left(\mathrm{P}_{2} \mathrm{O}_{7}\right)_{4}$ electrodes were made from $\mathrm{Ag}_{7} \mathrm{Fe}_{3}\left(\mathrm{P}_{2} \mathrm{O}_{7}\right)_{4}$ active material, carbon and polyvinylidene fluoride binder with the weight ratio of 85:10:5, which was mixed with N- 
methyl-2-pyrrolidone solvent and tape cast on $\mathrm{Al}$ foil. Polymeric separator and $1 \mathrm{M} \mathrm{LiBF}_{4}$ in 50/50 ethylene carbonate/ dimethyl carbonate electrolyte were used for all cells.

Three electrode cells were assembled in an Ar-filled glovebox with lithium foil as reference and counter electrodes. Three electrode cells were tested using a Biologic potentiostat using linear sweep voltammetry at $0.05 \mathrm{mV} / \mathrm{s}$ to a series of voltages: (1) OCV-3.434V, (2) OCV-3.096V, (3) OCV-2.332V, (4) OCV-2.0V. The electrodes were recovered in an Argon-filled glovebox and sealed between polyimide tape prior to $e x$-situ XRD measurements. The cell design for the synchrotron based measurements was a pouch type design (Figure 1(a)).

Two electrode coin type cells were tested using lithium metal as anode with a Maccor test station or Biologic potentiostat. Electrochemical impedance spectroscopy (EIS) measurements were collected as a function of discharge. The frequency range for impedance measurement was $1 \mathrm{MHz}$ to $5 \mathrm{mHz}$ with a $10 \mathrm{mV}$ amplitude. EIS data were fitted to equivalent circuits using Zview software. ${ }^{55}$ Galvanostatic discharge curved is obtained at C/15 rate with $1.0 \mathrm{~V}$ as discharge voltage limit. In pulse test, the same $\mathrm{C} / 15$ rate is used as the background discharge current and applied the $10 \mathrm{~mA} / \mathrm{cm}^{2}$ current density for 2s pulse every 1 hour with 4 hours rest time after each pulse.

Operando x-ray diffraction measurements were performed at beamline 6-ID-D at the Advanced Photon Source at Argonne National Laboratory. Using a monochromatic x-ray beam (wavelength $\lambda=0.123584 \pm 0.000025 \AA$, cross-sectional area $0.5 \times 0.5 \mathrm{~mm}^{2}$ ), the diffracted signal was measured using a Perkin Elmer area detector placed approximately $800 \mathrm{~mm}$ behind the cell (see Figure 1(b)). A similar setup geometry has been used in studies of in-situ lead zirconate titanate thin film growth ${ }^{56}$ and operando $\mathrm{Li}_{2} \mathrm{O}_{2}$ grain growth in $\mathrm{Li}_{-} \mathrm{O}_{2}$ batteries. ${ }^{57}$ In 
this study, the cell was discharged using a Maccor model 4300 battery tester using a constant current of $0.093 \mathrm{~mA}$, approximately C/15 discharge rate, for 15 hours. Diffraction patterns were obtained by measuring the bight-field images on the detector for 2 minutes. A diffraction pattern was collected every 10 minutes over a 15 hour period. 2D diffraction rings were integrated into 1D diffraction patterns using Fit2D V12.077 software (A.P. Hammersley, ESRF98HA01T) ${ }^{58}$ At the time of the measurement, APS was running in top-off mode and so changes to the beam intensity over time were minimal. The $\mathrm{Ag}(113)$ and $\mathrm{Al}(113)$ peak for each scan were fit using to a Voigt line shape with a linear background using PeakFit. ${ }^{59}$

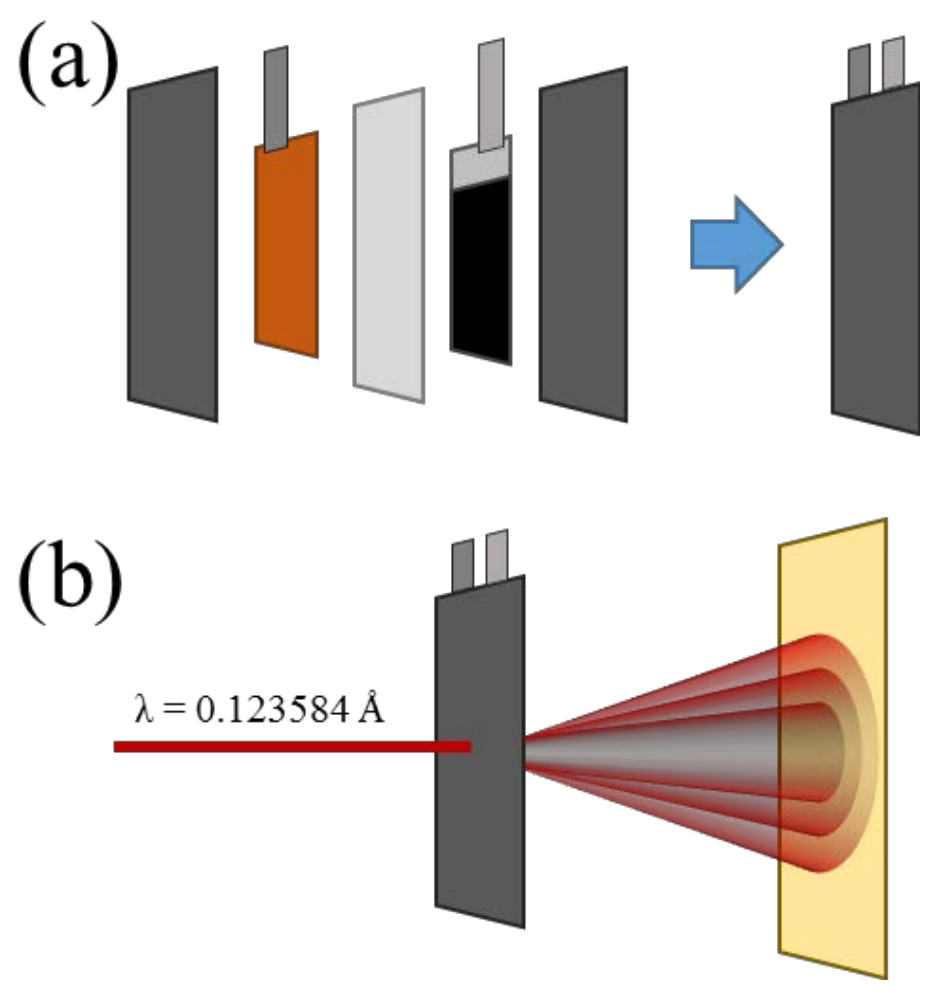

Figure 1. (a) Pouch cell components from left to right: plastic coated aluminum foil, Li metal anode on $\mathrm{Cu}$ foil (current collector), polypropylene separator, $\mathrm{Ag}_{7} \mathrm{Fe}_{3}\left(\mathrm{P}_{2} \mathrm{O}_{7}\right)_{4}$ electrode (with $\mathrm{Al}$ foil as current collector), another layer of plastic coated aluminum foil; (b) Operando XRD transmission experimental setup 


\section{Results and discussion}

\section{Material characterization results}

Figure 2 presents the XRD pattern from a laboratory diffractometer for the synthesized $\mathrm{Ag}_{7} \mathrm{Fe}_{3}\left(\mathrm{P}_{2} \mathrm{O}_{7}\right)_{4}$ material with the reference pattern (PDF no. 01-078-2996). No extra peaks were observed indicating a pure phase for the as-synthesized material. The structure details from the refinement have been discussed in our previous study. ${ }^{32}$ The elemental composition of the $\mathrm{Ag}_{7} \mathrm{Fe}_{3}\left(\mathrm{P}_{2} \mathrm{O}_{7}\right)_{4}$ material was determined by inductively coupled plasma-optical emission spectroscopy (ICP-OES). Measurement of thirty samples gave the $\mathrm{Na}$, Ag, and P elemental contents of $0.04+/-0.0071,7.50+/-0.48$, and $8.02+/-0.29$ respectively, with an average composition of $\mathrm{Na}_{0.04} \mathrm{Ag}_{7.50} \mathrm{Fe}_{3}\left(\mathrm{P}_{2.00} \mathrm{O}_{7}\right)_{4}$.

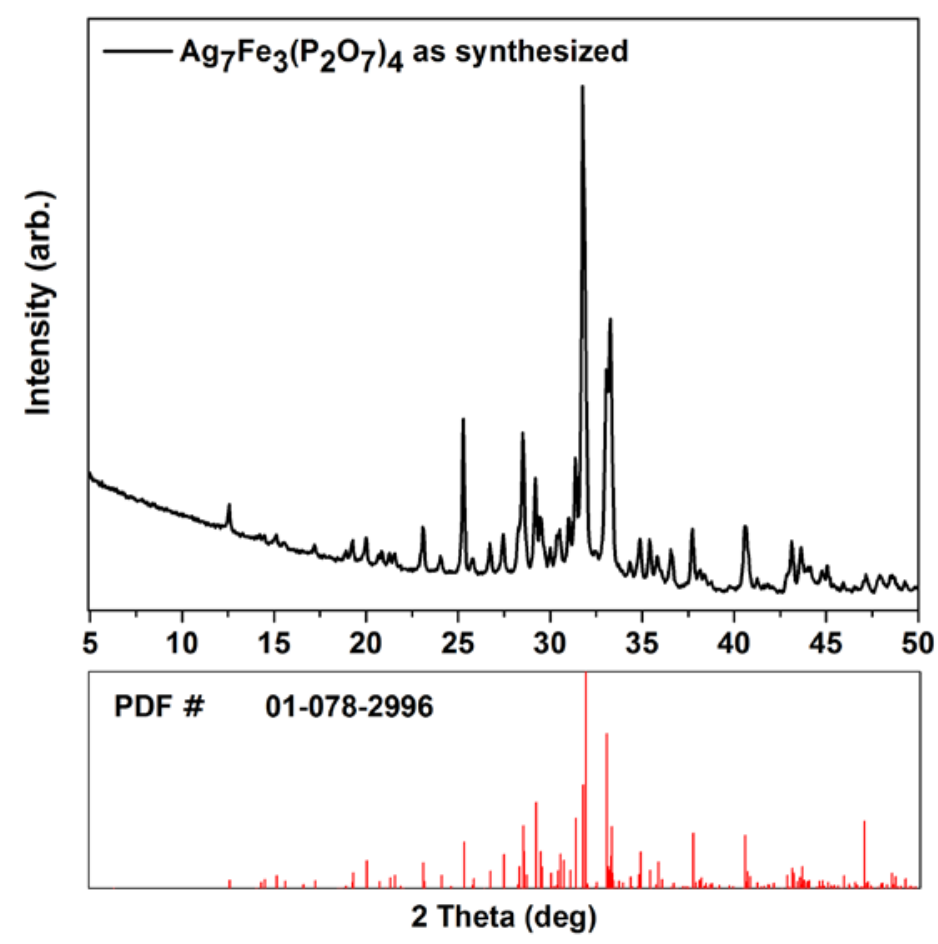

Figure 2. X-ray powder diffraction of as synthesized $\mathrm{Ag}_{7} \mathrm{Fe}_{3}\left(\mathrm{P}_{2} \mathrm{O}_{7}\right)_{4}$ 


\section{Electrochemical characterization}

Discharge curves (Figure 3(a)) were obtained from the $\mathrm{Li} / \mathrm{Ag}_{7} \mathrm{Fe}_{3}\left(\mathrm{P}_{2} \mathrm{O}_{7}\right)_{4}$ electrochemical cell using a galvanostatic test at a C/15 rate. The high voltage plateau at $3.1 \mathrm{~V}$ is $\sim 1.0$ electron equivalent (ee), followed by the long plateau to 6.6ee with operating voltage of $2.7 \mathrm{~V}$. The final 1.5 V plateau occurred from 6.8ee to 8ee, followed by a tail which reached 10ee. In order to identify the plateaus more clearly, the differential of charge over potential as a function of discharge potential was plotted (Figure 3(b)). Five resultant peaks in the differential charge plot were identified at voltage positons of $3.02 \mathrm{~V}, 2.87 \mathrm{~V}, 2.75 \mathrm{~V}, 2.46 \mathrm{~V}$ and $1.64 \mathrm{~V}$.
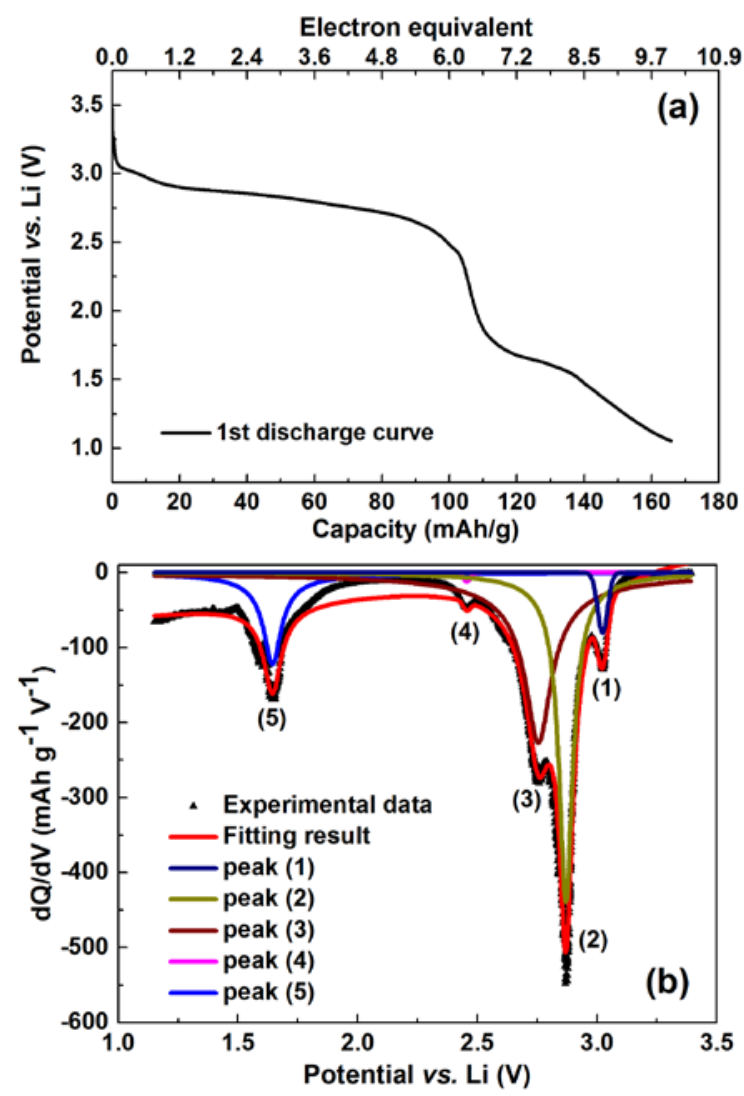

Figure 3. (a) Discharge curve and (b) Differential capacity plot of $\mathrm{Li} / \mathrm{Ag}_{7} \mathrm{Fe}_{3}\left(\mathrm{P}_{2} \mathrm{O}_{7}\right)_{4}$ electrochemical cell discharged at C/15 rate. 
In order to interpret the peaks in a quantitative way, the differential curve was fitted using Peak Fit software and the results are presented in Table 1. Based on the electron equivalents number of each peak, an electrochemical reaction mechanism was derived, which will be discussed in the operando section below.

\begin{tabular}{|c|c|c|c|}
\hline Peak ID & Peak Position (V) & $\begin{array}{r}\text { Peak Area/Capacity } \\
(\mathrm{mAh} / \mathrm{g})\end{array}$ & Electron Equivalents (ee) \\
\hline$(1)$ & 3.02 & 4.2 & 0.25 \\
\hline$(2)$ & 2.87 & 55.5 & 3.34 \\
\hline$(3)$ & 2.75 & 67.8 & 0.03 \\
\hline$(4)$ & 2.46 & 0.4 & 1.40 \\
\hline (5) & 1.64 & 23.1 & 9.1 \\
\hline Total & & 151 & \\
\hline
\end{tabular}

Table 1. Peak positions, peak areas (capacities) and their corresponding electron equivalents from the Peakfit results.

\section{Alternating current impedance studies}

Figure 4(a) shows the discharge profile for the initial 1.0ee. The arrows on the discharge curve indicate depths of discharge to $0,0.1,0.25,0.5$ and 1.0ee which are also the points where the impedance data was acquired. There is a steady decrease in the internal resistance of the cell as a function of discharge indicated by the AC impedance (ACI) data. The Nyquist plot (Figure 4(b)) shows a decrease in the diameter of the semi-circles at higher depths of discharge. The Bode plot (Figure 4(c)), impedance as a function of frequency is shown, demonstrating a decrease in impedance most notably in the low frequency range. The equivalent circuit used for the fits is 
shown in Figure 4(d), where $\mathrm{R}_{s}$ is the solution resistance, $\mathrm{R}_{\mathrm{m}}$ is the resistance at the Li interface and $\mathrm{R}_{c t}$ refers to the charge-transfer resistance of the cathode. ${ }^{51,60}$ Table 2 lists $\mathrm{R}_{s}, \mathrm{R}_{\mathrm{m}}$ and $\mathrm{R}_{c t}$ derived from the equivalent circuit fits. The initial $\mathrm{R}_{c t}$ is $41 \mathrm{Ohm}$ with an absolute resistance of $300 \mathrm{Ohm}$ at $0.01 \mathrm{~Hz}$.

Based on the fitting results of the ACI data, the charge transfer resistance decreases as a function of DOD, which is consistent with the formation of metallic silver. Percolation theory can be used to predict the minimum amount of conductor needed to provide a consistent conductive path and an associated increase in conductivity of a bulk electrode. ${ }^{49}$ For the $\mathrm{Ag}_{7} \mathrm{Fe}_{3}\left(\mathrm{P}_{2} \mathrm{O}_{7}\right)_{4}$ electrode composition used in this study, the threshold for electrode percolation has already been surpassed, due to the presence of $10 \%$ conductive carbon additive. However, it is important to note that intraparticle conductivity can also be a barrier, ${ }^{31}$ where a percolation network may be necessary but not sufficient to achieve full utilization of an electroactive material. ${ }^{61}$ The fitting results of the impedance spectroscopy data showed a rapid decrease (19\%) of $\mathrm{R}_{\mathrm{ct}}$ at 0.1 ee, coincident with formation of $\mathrm{Ag}^{0}$ as discussed below. The change in $\mathrm{R}_{\mathrm{ct}}$ becomes less significant after 0.5 ee discharge where the $\mathrm{R}_{\mathrm{ct}}$ remains at $\sim 25 \mathrm{Ohm}$ at 1ee and 2ee discharge. 


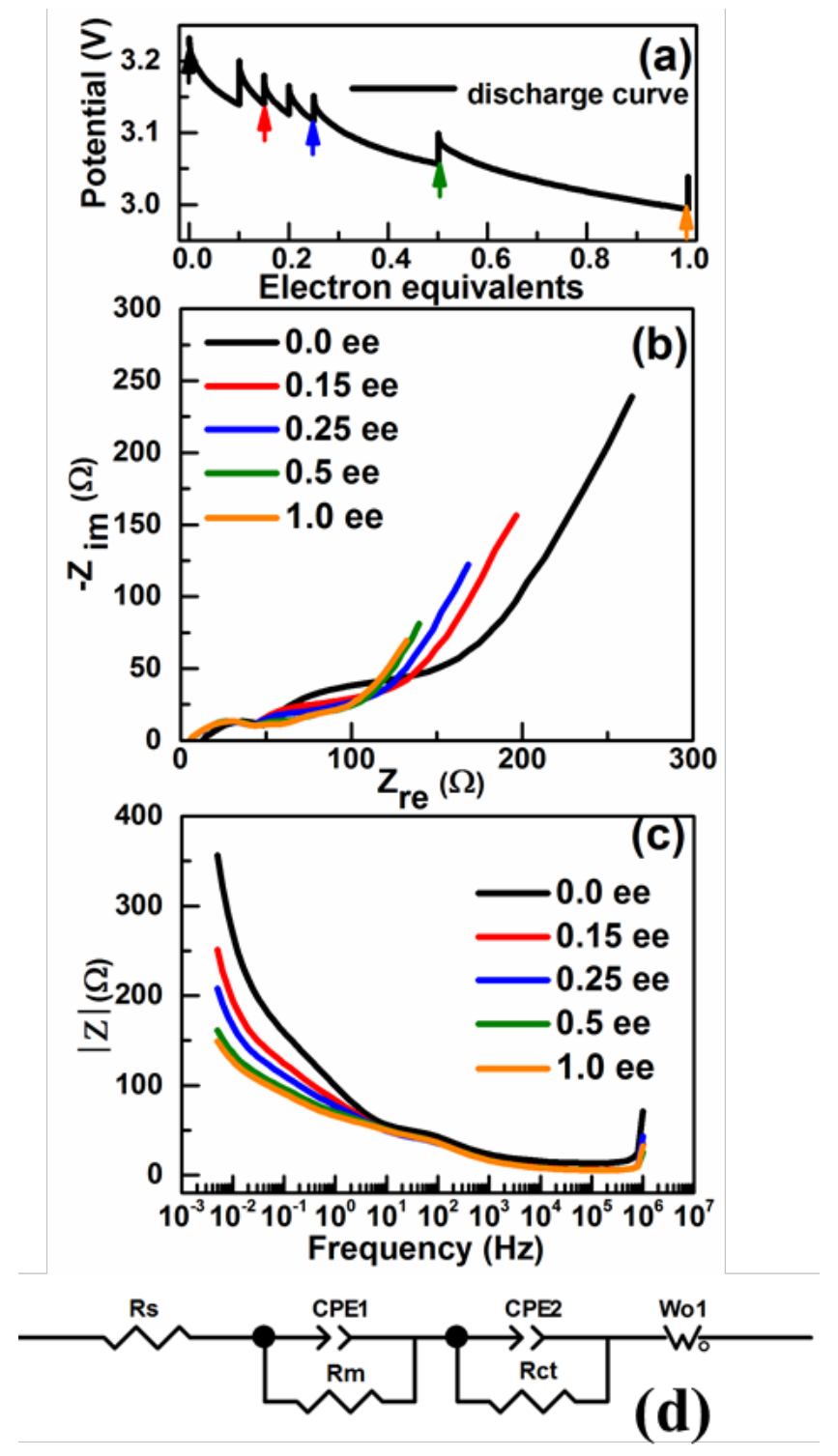

Figure 4. (a) Discharge profile for low depth of discharge (DOD), the arrows indicate the electron equivalent (ee) values with corresponding AC impedance measurements; (b) Nyquist plot of the AC impedance response of $\mathrm{Ag}_{7} \mathrm{Fe}_{3}\left(\mathrm{P}_{2} \mathrm{O}_{7}\right)_{4} / \mathrm{Li}$ cell at undischarged, 0.15 ee, 0.25ee, 0.5ee and 1ee DOD; (c) Absolute value of the AC impedance as a function of frequency at different DOD and (d) Equivalent circuit model used for fit. 


\begin{tabular}{|c|c|c|c|c|c|c|c|}
\hline DOD & 0 & 0.1 & 0.15 & 0.2 & 0.25 & 0.5 & 1 \\
\hline $\mathrm{R}_{\mathrm{s}}$ & $13.9(2)$ & $5.7(1)$ & $5.6(1)$ & $5.7(1)$ & $5.5(0.1)$ & $5.5(1)$ & $5.6(1)$ \\
$(\mathrm{Ohm})$ & & & & & & & \\
\hline $\mathrm{R}_{\mathrm{m}}$ & $30.7(2)$ & $35.8(1)$ & $36.9(1)$ & $37.2(2)$ & $37.5(1)$ & $39.5(3)$ & $39.4(5)$ \\
$(\mathrm{Ohm})$ & & & & & & & \\
\hline $\mathrm{R}_{c t}$ & $40.7(5)$ & $33.1(3)$ & $31.4(2)$ & $30.6(4)$ & $27.8(3)$ & $26.7(6)$ & $26.9(1)$ \\
$(\mathrm{Ohm})$ & & & & & & & \\
\hline
\end{tabular}

Table 2. Fitting results of AC impedance data to resistance elements of equivalent circuit model

\section{Ex-situ x-ray diffraction}

The ex-situ samples were prepared by cyclic voltammetry sweep at $0.05 \mathrm{mV} / \mathrm{s}$ rate, and the end potential for each sample are indicated with grey dots in Figure 5(a). Ex-situ X-ray diffraction from $\mathrm{Cu} \mathrm{K} \alpha$ radiation reveals the formation of $\mathrm{Ag}$ metal in discharged $\mathrm{Ag}_{7} \mathrm{Fe}_{3}\left(\mathrm{P}_{2} \mathrm{O}_{7}\right)_{4}$ electrodes. Figure 5(b) shows the XRD pattern for discharged electrodes along with the undischarged $\mathrm{Ag}_{7} \mathrm{Fe}_{3}\left(\mathrm{P}_{2} \mathrm{O}_{7}\right)_{4}$ electrode. The Ag metal diffraction peak is observed for the lowest depth of discharge electrode (reduced to $3.43 \mathrm{~V}$ ), indicating $\mathrm{Ag}^{+}$ions are preferentially reduced. The Ag(111) peak was fitted to quantify the Ag metal based on the peak area and derive the crystallite size from the Scherrer equation. The fits are shown in the inset graph in Figure 5(b). The experimental data are indicated in different colors for each electrode while the fitted lines are expressed in grey. The amount of metallic silver increases as the electrodes are discharged to greater depth (low voltage), as shown by the increase in peak intensity and area. 
The area of the $\mathrm{Ag}(111)$ peak is plotted as a function of discharge voltage (Figure 5(c)). The peak area increases with reduction indicating that $\mathrm{Ag}^{+}$ions are reduced to form $\mathrm{Ag}$ metal. The increase in peak area is nonlinear and the largest change in the amount of Ag metal formation occurs between $3.10 \mathrm{~V}$ and $2.33 \mathrm{~V}$, with a small change between $2.33 \mathrm{~V}$ and $2.0 \mathrm{~V}$. These results indicate that a significant amount of Ag metal formation takes place during the early stage of discharge. In the later stages of discharge, the amount of Ag continues to increase, but to a lesser extent. The average Ag metal crystallite size (as determined by the peak width) is plotted as a function of depth of discharge in red in Figure 5(c), where no significant change in size is observed. As more Ag metal accumulates during the reduction process, more heterogeneous nuclei of Ag metal form due to the multiple locations of $\mathrm{Ag}^{+}$ions sites in the $\mathrm{Ag}_{7} \mathrm{Fe}_{3}\left(\mathrm{P}_{2} \mathrm{O}_{7}\right)_{4}$ structure. Therefore, although the amount of $\mathrm{Ag}^{0}$ increases significantly, the average $\mathrm{Ag}^{0}$ crystallite size remains unchanged throughout discharge. 

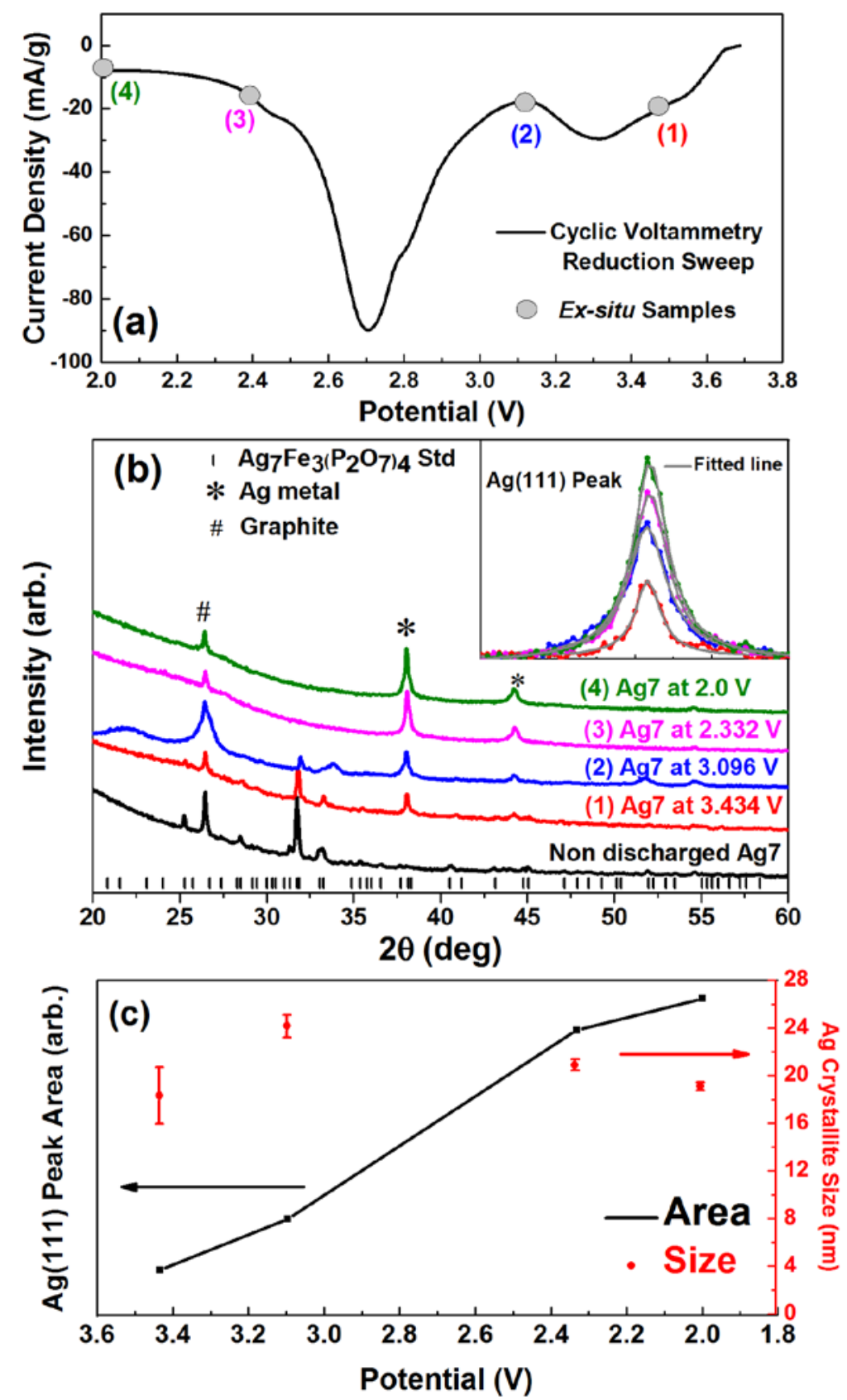

Figure 5. (a) Cyclic voltammetry sweep for the first reduction segment, grey dots indicate the samples for ex-situ XRD ; (b) XRD pattern of $\mathrm{Ag}_{7} \mathrm{Fe}_{3}\left(\mathrm{P}_{2} \mathrm{O}_{7}\right)_{4}$ electrodes discharged to different voltages, Ag(111) peak fit detail shown in inset graph; (c) Fitted area as a function of depth of discharge (black) and Ag metal crystallite size for each electrode (red). 


\section{Scanning electron microscope images}

The SEM images for undischarged, discharged to $2.76 \mathrm{~V}$ (3.6 ee) and discharged to $2.50 \mathrm{~V}$ (7.7

ee) electrodes are shown in Figure 6. In the undischarged electrode, $\operatorname{Ag}_{7} \mathrm{Fe}_{3}\left(\mathrm{P}_{2} \mathrm{O}_{7}\right)_{4}$ material shows a plate-like shape with maximum dimensions of $2 \mu \mathrm{m} \times 4 \mu \mathrm{m}$. The plates lay flat due to the pressure applied during electrode preparation. In the discharged electrode, shown in $\left(\mathrm{b}_{1}\right)$, the white contrast indicated the presence of Ag metal formed from the reduction-displacement reaction. Energy dispersive spectroscopy (EDS) analysis on Ag metal content in three locations of interest is shown in the embedded table. Compared with the Ag content of the undischarged electrode, the Ag concentration is higher in the white region (red mark) and decreased in the dark area (orange mark) for the discharged electrode. This result illustrates that $\mathrm{Ag}^{+}$ions are mobile during discharge, which confirms our assumption in the previous report. ${ }^{32}$

A thresholding and inverse image analysis was done to quantify the size and relative position of the silver deposits. Specifically, Figure $6\left(\mathbf{b}_{2}\right)$ and $\left(\mathbf{c}_{2}\right)$ clearly shows the Ag metal particles in black for 3.6 ee and 7.7 ee reduction respectively in order to obtain the size and nearest neighbor distributions (NND) analysis results (Figure 7). The NND method was used to quantify the spatial location of Ag metal formed with discharge in which the distance $r$ is defined as the distance between the centroid of a particle and that of its nearest neighbor. ${ }^{62}$ Notably, although the silver crystallite size does not change as a function of depth of reduction as evidenced from the ex-situ XRD data discussed above, the average $\mathrm{Ag}^{0}$ deposit size and distribution of the $\mathrm{Ag}^{0}$ deposits changes, as seen by SEM. In the 7.7ee reduction electrode $\left(0.04 \mu \mathrm{m}^{2}\right)$ the $\mathrm{Ag}^{0}$ deposits are seven times smaller than that in the 3.6 ee reduction sample $\left(0.3 \mu \mathrm{m}^{2}\right)$. Both samples have the highest population at the smallest size region of $0-0.05 \mu \mathrm{m}^{2}$. However, the 7.7ee reduction sample show higher incidence (52\%) than the 3.6ee electrodes (38\%) at this range and lower 
incidence at other regions above $0.05 \mu \mathrm{m}^{2}$. Therefore, the 7.7ee reduction sample showed a smaller $\mathrm{Ag}^{0}$ deposit size than the 3.6ee reduction sample. In addition, the 7.7ee reduction electrode had shorter NND than the 3.6ee electrode, indicated by higher NND frequency below $0.6 \mu \mathrm{m}$ and lower frequency above $0.8 \mu \mathrm{m}$ distance (Figure $\mathbf{7 ( b )}$ ). Thus, in the 7.7ee reduction sample, we are closer to the goal of wiring every electroactive particle.

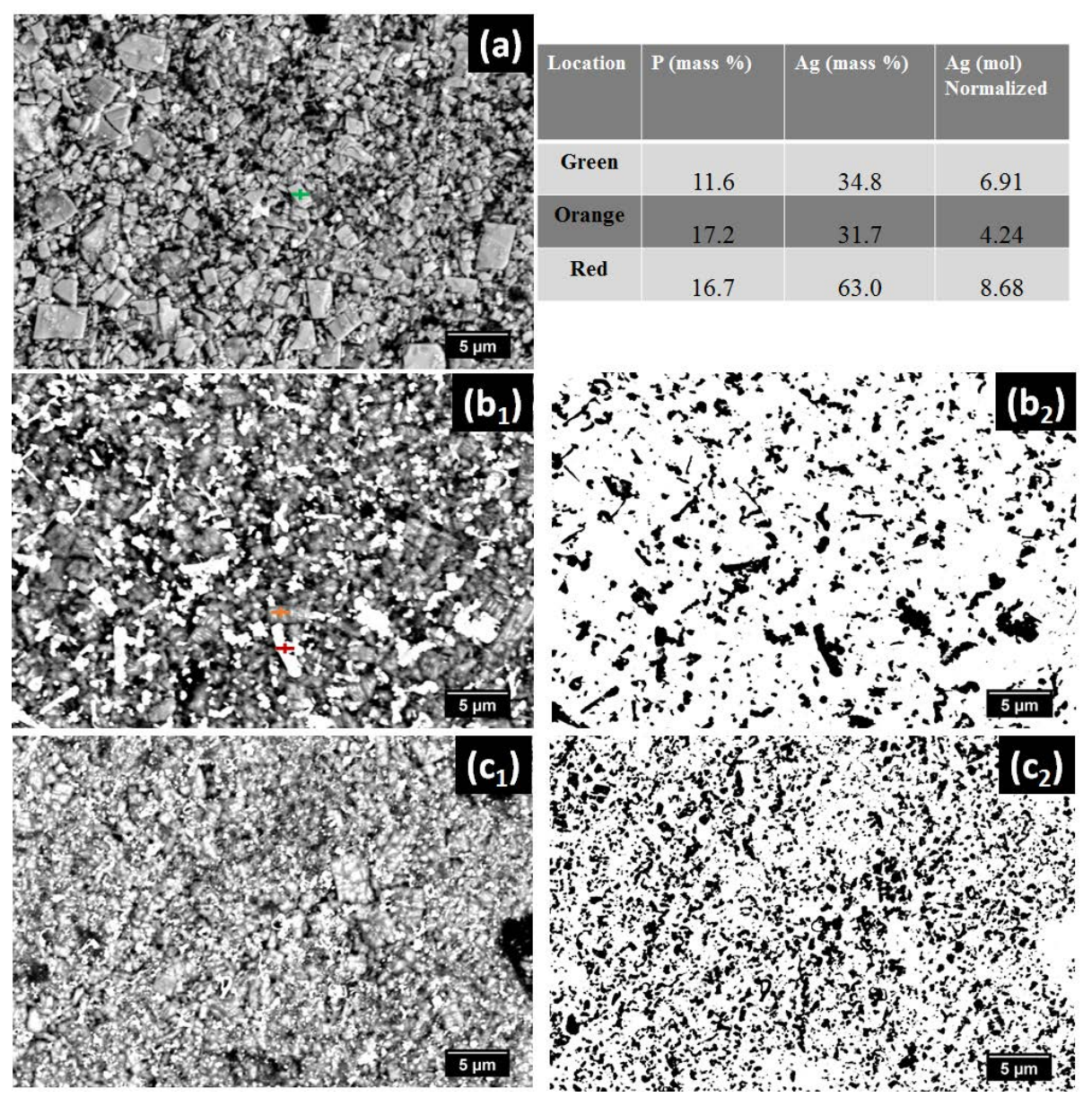

Figure 6. SEM images from undischarged coating (a), discharged to $2.76 \mathrm{~V}$ (3.6 ee) $\mathbf{( b}_{\mathbf{1}}$ ) and discharged to $2.50 \mathrm{~V}$ (7.7 ee) $\left(\mathbf{c}_{\mathbf{1}}\right)$. The table shows the mass percentage of $\mathrm{P}$ and Ag element from EDS mapping of the green, orange and red locations and also the normalized Ag content. $\left(\mathbf{b}_{2}\right)$ and $\left(\mathbf{c}_{2}\right)$ show the clear location of Ag metal particles in black for corresponding $\left(\mathbf{b}_{1}\right)$ and $\left(\mathbf{c}_{1}\right)$, respectively. 

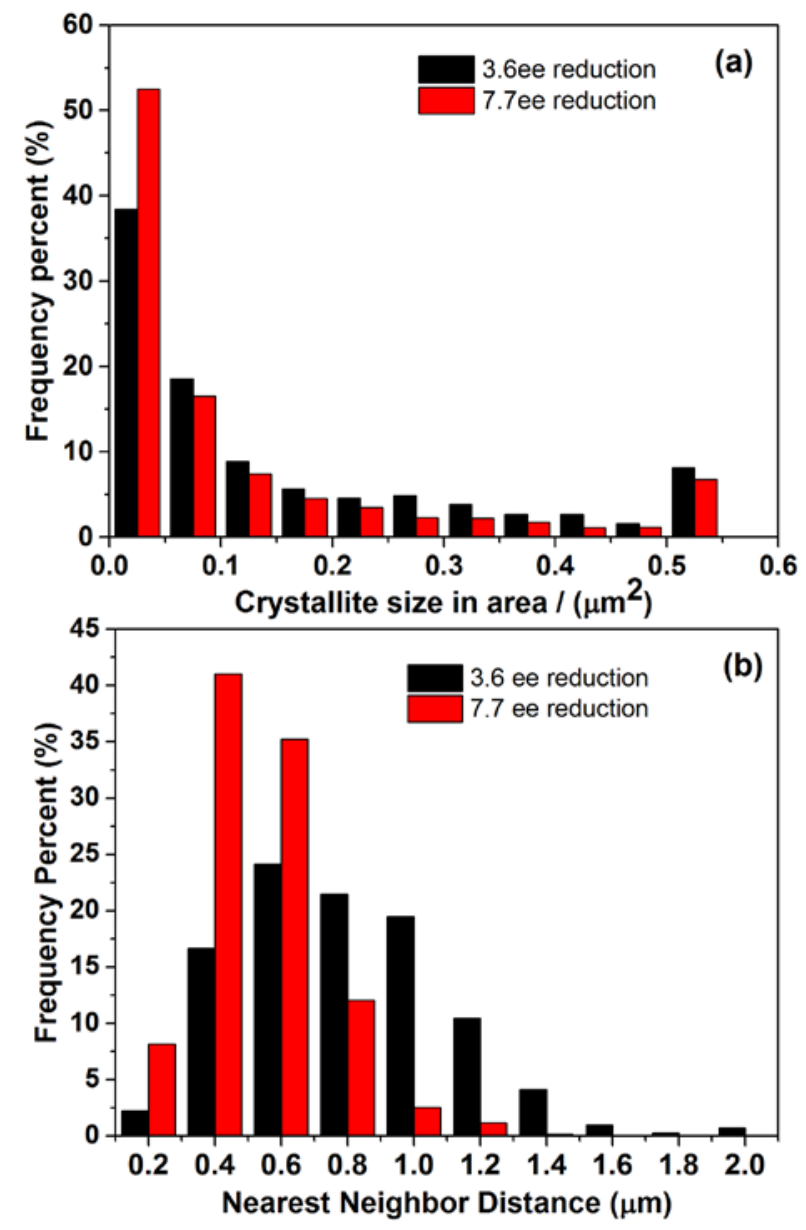

Figure 7. Ag metal crystallite size distributions (a) and nearest neighbor distance (b) analysis for 3.6 ee and 7.7 ee reduction samples

\section{Operando x-ray diffraction}

Using a high energy ( $100 \mathrm{keV})$ synchrotron x-ray beam, we studied the formation of silver metal and evolution of the $\mathrm{Ag}_{7} \mathrm{Fe}_{3}\left(\mathrm{P}_{2} \mathrm{O}_{7}\right)_{4}$ cathode material upon electrochemical reduction operando by measuring the diffraction pattern as a function of discharge. Due to the geometry of the experiment (Figure 1), the measured diffraction pattern contains peaks from the aluminum pouch material, aluminum foil cathode, and copper foil anode current collectors in addition to the active cathode material $\mathrm{Ag}_{7} \mathrm{Fe}_{3}\left(\mathrm{P}_{2} \mathrm{O}_{7}\right)_{4}$ and silver metal. Silver and aluminum have similar 
crystal structures: both are face-centered cubic with comparable lattice constants (Ag: $4.0862 \AA$ from AMCSD \#0011135, Al: $4.04958 \AA$ from AMCSD \#0011136). Because of this, at low angles the presence of silver is obscured by the aluminum foil and pouch material. Nonetheless, due to the high intensity of the synchrotron based XRD and the high precision of the data, we are able to differentiate the Ag metal peak from the Al peak and resolve Ag metal peak at high diffraction angles.

$\mathrm{Cu}, \mathrm{Al}, \mathrm{Ag}$ metal and $\mathrm{Ag}_{7} \mathrm{Fe}_{3}\left(\mathrm{P}_{2} \mathrm{O}_{7}\right)_{4}$ electrode peaks are indicated in the stack plots of the diffraction patterns (Figure 8(a)). The associated discharge curve is shown on the right. $\mathrm{Ag}(113)$ and $\mathrm{Al}(113)$ peaks, indicated in the red box (20 region of .45 - 7.6 degrees), are used for the analysis. $\mathrm{Ag}_{7} \mathrm{Fe}_{3}\left(\mathrm{P}_{2} \mathrm{O}_{7}\right)_{4}$ peak evolution in the $2 \theta$ region of 2 to 3.5 deg are shown in Figure 8(b). With lithiation to 2.5ee (scan 9, shown in red), peak (11-9) shifted to higher diffraction angle, indicating the decrease of cell parameters due to the displacement of $\mathrm{Ag}^{+}$ions with substitution of smaller radii of $\mathrm{Li}^{+}$cation. However, (22-5) peak position (2.625 deg) does not change during the discharge except a shoulder peak at 2.70 deg appears at 2.5ee (scan 9, red) and distinguishes at 7.0ee (scan 24, blue). Area from peak (22-5) from each scan is derived to track the change of $\mathrm{Ag}_{7} \mathrm{Fe}_{3}\left(\mathrm{P}_{2} \mathrm{O}_{7}\right)_{4}$ electrode. 


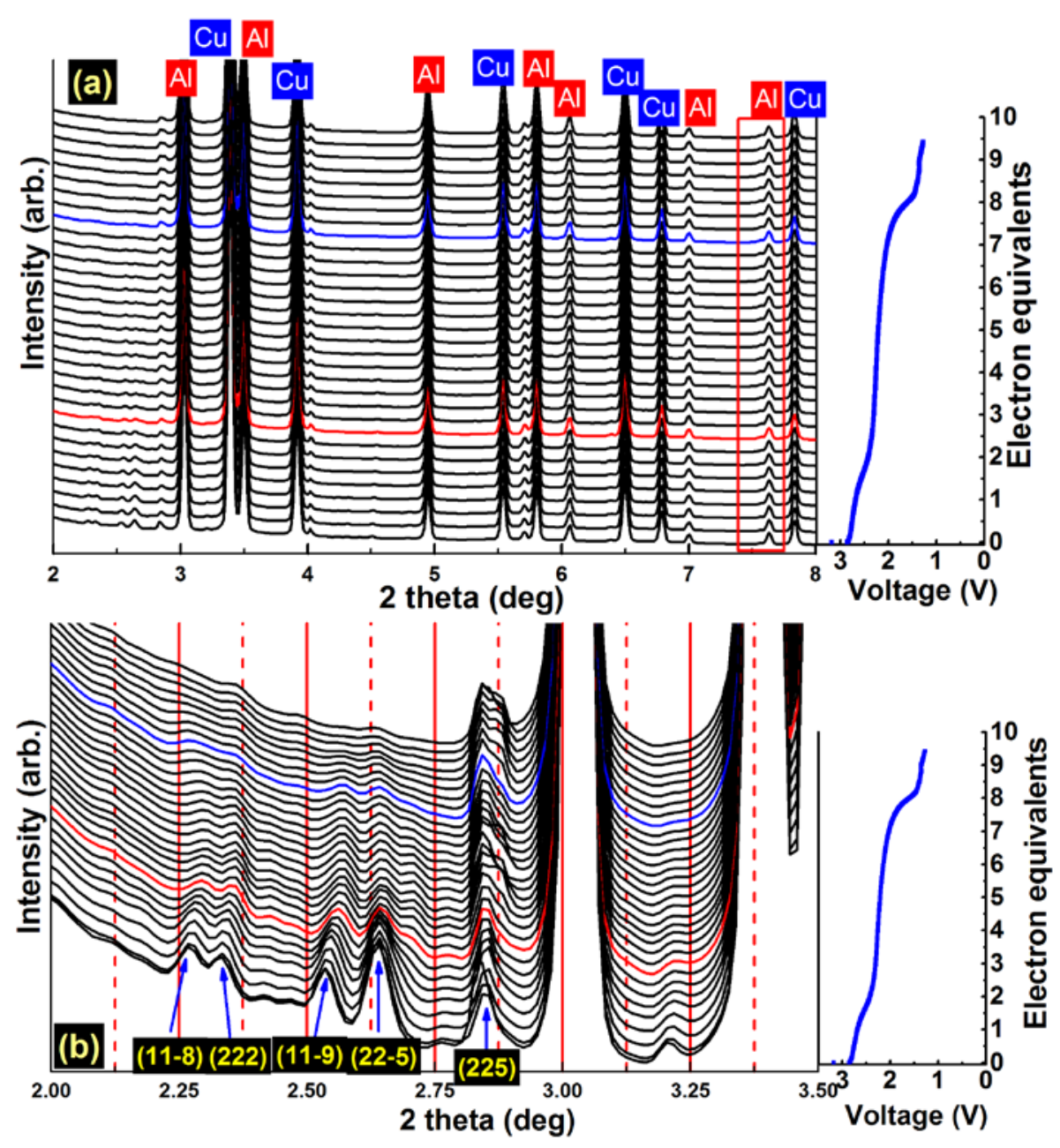

Figure 8. Stack plot of 32 scans of operando synchrotron XRD from undischarged to fully discharged $(\lambda=0.123584 \AA$ ). In (a), the high intensity peaks from $\mathrm{Cu}$ and $\mathrm{Al}$ are labeled, Ag(113) and Al(113) peaks used for Ag metal analysis are indicated in the red box; (b) Peak evolution of $\mathrm{Ag}_{7} \mathrm{Fe}_{3}\left(\mathrm{P}_{2} \mathrm{O}_{7}\right)_{4}$ electrode upon discharge. Solid and dotted red lines are provided every 0.125 degree for visual reference.

The Ag(113) and $\mathrm{Al}(113)$ peaks are separated by $\sim 0.1$ degree which is sufficient in the resolution of our experiment to resolve the peaks clearly, as indicated in Figure 9. Before discharge there is a small amount of metallic silver present (Figure 9(a)) probably due to the ion exchange behavior of $\mathrm{Ag}_{7} \mathrm{Fe}_{3}\left(\mathrm{P}_{2} \mathrm{O}_{7}\right)_{4}$ material and some reduction at the lithium anode surface. With 
relatively high mobility of $\mathrm{Ag}^{+}$ions in the structure, ion exchange between $\mathrm{Li}^{+}$from the electrolyte and $\mathrm{Ag}^{+}$in $\mathrm{Ag}_{7} \mathrm{Fe}_{3}\left(\mathrm{P}_{2} \mathrm{O}_{7}\right)_{4}$ framework is likely to be kinetically favorable. This phenomenon has also observed in previous studies of materials containing mobile $\mathrm{Ag}^{+}$ions, such as $\mathrm{Ag}_{2} \mathrm{VP}_{2} \mathrm{O}_{8}$ and $\mathrm{Ag}_{2} \mathrm{VO}_{2} \mathrm{PO}_{4}$ where $\mathrm{Ag}$ metal peaks were identified on the surface of the $\mathrm{Li}$ anode with energy dispersive X-ray diffraction (EDXRD) technique. ${ }^{49-50}$
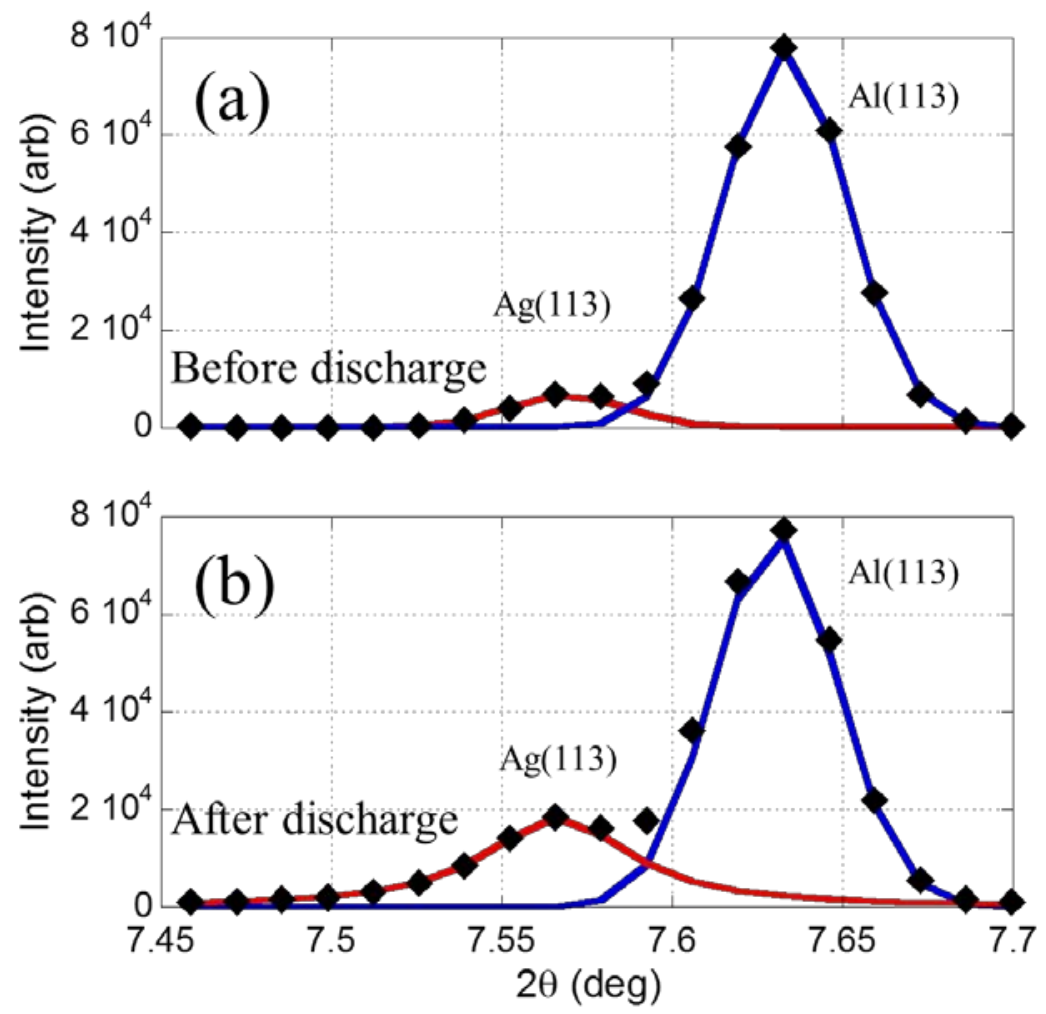

Figure 9. Results of fitting $\mathrm{Ag}(331)$ and $\mathrm{Al}(331)$ peaks before discharge (a) and after fully discharge (b)

To quantify the amount of silver metal present and the corresponding decrease of the parent $\mathrm{Ag}_{7} \mathrm{Fe}_{3}\left(\mathrm{P}_{2} \mathrm{O}_{7}\right)_{4}$ material, the $\mathrm{Ag}(113)$ and $\mathrm{Ag}_{7} \mathrm{Fe}_{3}\left(\mathrm{P}_{2} \mathrm{O}_{7}\right)_{4}(22-5)$ peak areas as a function of discharge are shown in Figure 10. To account for small changes in the beam intensity as a function of time, the $\mathrm{Ag}(113)$ and $\mathrm{Ag}_{7} \mathrm{Fe}_{3}\left(\mathrm{P}_{2} \mathrm{O}_{7}\right)_{4}(22-5)$ peak areas were normalized to the area of 
the $\mathrm{Al}(113)$ peak. The $\mathrm{Ag}(113)$ peak area evolution could be divided into three regions based on the change in its slope and the plateaus in the $\mathrm{Li} / \mathrm{Ag}_{7} \mathrm{Fe}_{3}\left(\mathrm{P}_{2} \mathrm{O}_{7}\right)_{4}$ discharge curve. These three regions were assigned to their corresponding electrochemical reactions indicated in Scheme 1. The rapid increase in the amount of silver metal in region 1, is associated with peaks (1) and (2) in Figure 3(b) and the R1, R2 reactions in Scheme 1. This region corresponds to the first plateau and the beginning of the second plateau (below $50 \mathrm{mAh} / \mathrm{g}$, 3.0 electron equivalent), indicating that the onset of $\mathrm{Ag}^{+}$ions reduction occurred before the onset of $\mathrm{Fe}^{3+}$ reduction. Notably, AC impedance spectroscopy shows a significant decrease in cell resistance after only the initial 0.1 ee discharge. Correspondingly, the $\mathrm{Ag}_{7} \mathrm{Fe}_{3}\left(\mathrm{P}_{2} \mathrm{O}_{7}\right)_{4}(22-5)$ peak area decreases dramatically in this region indicating the displacement of $\mathrm{Ag}^{+}$ions significantly affects the crystallinity of the parent structure.

Next, the amount of silver increases more slowly during the second plateau (3.0ee to 8.0ee), which is due to the involvement of $\mathrm{Fe}^{3+}$ reduction, indicated by the peak (3) in Figure 3(b) and the $\mathrm{R} 3$ reaction in Scheme 1. In concert, the $\mathrm{Ag}_{7} \mathrm{Fe}_{3}\left(\mathrm{P}_{2} \mathrm{O}_{7}\right)_{4}(22-5)$ peak area continues to decrease, albeit more slowly than in Region 1 . Above 8.0ee (133 mAh/g), silver metal increases more rapidly than in the second plateau, indicating that mostly $\mathrm{Ag}^{+}$ions reduction occurs here, as illustrated in the $\mathrm{R} 4$, $\mathrm{R} 5$ reactions. The $\mathrm{Ag}_{7} \mathrm{Fe}_{3}\left(\mathrm{P}_{2} \mathrm{O}_{7}\right)_{4}(22-5)$ peak area reaches its minimum at the end of discharge. 

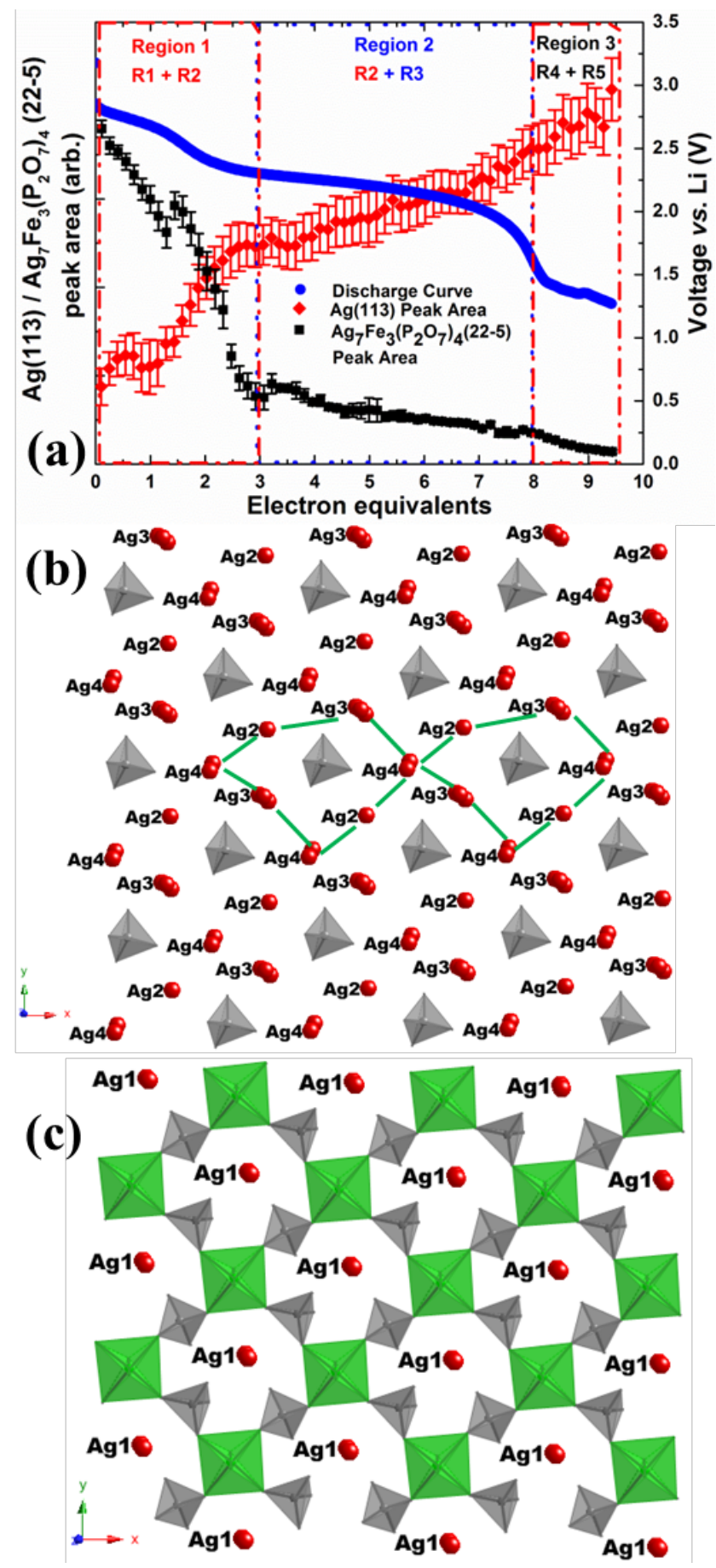

Figure 10. (a) Analysis on $\mathrm{Ag}(113)$ peak area (red) and $\mathrm{Ag}_{7} \mathrm{Fe}_{3}\left(\mathrm{P}_{2} \mathrm{O}_{7}\right)_{4}(22-5)$ peak area (black) evolution along with the discharge curve (blue). The corresponding reactions (R1, R2, R3, R4 and R5) from Scheme 1 listed below are also shown. Error bars come from uncertainty in PeakFit fit to peaks. Intensities of $\mathrm{Ag}(113)$ and $\mathrm{Ag}_{7} \mathrm{Fe}_{3}\left(\mathrm{P}_{2} \mathrm{O}_{7}\right)_{4}(22-5)$ peaks are normalized to the 
intensity of the $\mathrm{Al}(113)$ peak to adjust for small variations in beam intensity over time; (b) Two dimensional diffusion path showing the locations of $\operatorname{Ag}(2), \operatorname{Ag}(3)$ and $\operatorname{Ag}(4)$. The $A g(4)$ sites are at intersections while the and $\operatorname{Ag}(2)$ and $\operatorname{Ag}(3)$ sites are on the path with directions of $(\boldsymbol{a}+\boldsymbol{b})$ and ( $\boldsymbol{a}$ - $\boldsymbol{b})$, respectively; (c) Ag(1) site plane, where the mobility is hindered by the surrounding $\mathrm{FeO}_{6}$ octahedra (green) and $\mathrm{PO}_{4}$ tetrahedra (grey).

$$
\begin{aligned}
& \text { (R1) } \mathrm{Ag}_{7} \mathrm{Fe}(\mathrm{III})_{3}\left(\mathrm{P}_{2} \mathrm{O}_{7}\right)_{4} \stackrel{\mathrm{xLi}^{+}(0<\mathrm{x} \leq 0.25)}{\longrightarrow} \mathrm{Li}_{\mathrm{x}} \mathrm{Ag}_{7-\mathrm{x}} \mathrm{Fe}(\mathrm{III})_{3}\left(\mathrm{P}_{2} \mathrm{O}_{7}\right)_{4}+\mathrm{xAg}^{0} \\
& \text { (R2) } \mathrm{Li}_{\mathrm{x}} \mathrm{Ag}_{7-\mathrm{x}} \mathrm{Fe}(\mathrm{III})_{3}\left(\mathrm{P}_{2} \mathrm{O}_{7}\right)_{4}+\mathrm{xAg}^{0} \stackrel{\mathrm{yLi}^{+}(0<\mathrm{y} \leq 3.34)}{\longrightarrow} \mathrm{Li}_{0.25+\mathrm{y}} \mathrm{Ag}_{6.75-\mathrm{y}} \mathrm{Fe}(\mathrm{III})_{3}\left(\mathrm{P}_{2} \mathrm{O}_{7}\right)_{4}+(0.25+\mathrm{y}) \mathrm{Ag}^{0} \\
& \text { (R3) } \mathrm{Li}_{0.25+\mathrm{y}} \mathrm{Ag}_{6.75-\mathrm{y}} \mathrm{Fe}(\mathrm{III})_{3}\left(\mathrm{P}_{2} \mathrm{O}_{7}\right)_{4}+(0.25+\mathrm{y}) \mathrm{Ag}^{0} \stackrel{\left(\mathrm{z}_{1}+z_{2}\right) \mathrm{Li}^{+}\left(0<z_{1} \leq 3 \text { and } 0<z_{2} \leq 1.08\right)}{\longrightarrow} \mathrm{Li}_{\left(3.59+z_{1}+z_{2}\right)} \mathrm{Ag}_{3.16} \mathrm{Fe}(\mathrm{II})_{3}\left(\mathrm{P}_{2} \mathrm{O}_{7}\right)_{4} \\
& +\left(3.59+z_{2}\right) \mathrm{Ag}^{0} \\
& \text { (R4) } \mathrm{Li}_{\left(3.59+z_{1}+z_{2}\right)} \mathrm{Ag}_{3.16} \mathrm{Fe}(\mathrm{II})_{3}\left(\mathrm{P}_{2} \mathrm{O}_{7}\right)_{4}+\left(3.59+z_{2}\right) \mathrm{Ag}^{0} \stackrel{\mathrm{uLi}^{+}(0<\mathrm{u} \leq 0.03)}{\longrightarrow} \mathrm{Li}_{7.67+\mathrm{u}} \mathrm{Fe}(\mathrm{II})_{3}\left(\mathrm{P}_{2} \mathrm{O}_{7}\right)_{4}+(\mathrm{u}+4.67) \mathrm{Ag}^{0} \\
& \text { (R5) } \mathrm{Li}_{7.67+\mathrm{u}} \mathrm{Fe}(\mathrm{II})_{3}\left(\mathrm{P}_{2} \mathrm{O}_{7}\right)_{4}+(\mathrm{u}+4.67) \mathrm{Ag}^{0} \stackrel{\mathrm{vLi}^{+}(0<\mathrm{v} \leq 1.40)}{\longrightarrow} \mathrm{Li}_{7.70+\mathrm{v}} \mathrm{Fe}(\mathrm{II})_{2.9}\left(\mathrm{P}_{2} \mathrm{O}_{7}\right)_{4}+(4.70+\mathrm{v}) \mathrm{Ag}^{0}
\end{aligned}
$$

Scheme 1. Lithiation and reduction-displacement processes upon cycle 1 reduction of $\mathrm{Ag}_{7} \mathrm{Fe}_{3}\left(\mathrm{P}_{2} \mathrm{O}_{7}\right)_{4}$ from galvanostatic discharge.

From the operando XRD and galvanostatic discharge curve studies, we conclude that the first plateau and the beginning of the second plateau (to 3.0 ee) are both associated with the formation of $\mathrm{Ag}^{0}$. This is consistent with the $\mathrm{AC}$ impedance results where the significant decrease in $\mathrm{R}_{\mathrm{ct}}$ occurs at as early as 0.1 ee discharge due to the formation of conductive $\mathrm{Ag}^{0}$ network. The exsitu XRD showed the same result where the $\mathrm{Ag}^{0}$ diffraction peak present after the first CV peak at $3.43 \mathrm{~V}$. The rest of the second plateau (from 3.0ee to 8.0ee) is associated with both $\mathrm{Ag}^{+}$and $\mathrm{Fe}^{3+}$ reduction. At the end of discharge (8.0ee to 9.4ee), the reaction is $\mathrm{Ag}^{+}$ion reductiondisplacement. The electrochemical reactions indicated from operando XRD match very well 
with the electron equivalents assignment from the galvanostatic study. These results are consistent with the assignment of each peak from the prior slow scan cyclic voltammetry of $\mathrm{Li} / \mathrm{Ag}_{7} \mathrm{Fe}_{3}\left(\mathrm{P}_{2} \mathrm{O}_{7}\right)_{4}{ }^{32}$ The $\mathrm{Ag}^{+}$ions in $\mathrm{Ag}(4)$ site are reduced first, due to its location in the diffusion path, followed by the $\mathrm{Ag}(3)$ and $\mathrm{Ag}(2)$ sites (Figure 10(b)). Notably, the $\mathrm{Ag}(1)$ site is reduced last since it is off the 2D diffusion plane has the lowest $\mathrm{Ag}^{+}$ion mobility among the various sites (Figure 10(c)).

\section{Effect of Ag metal formation on the cathode Ohmic resistance}

To investigate the effect of the Ag metal formation on the cell performance, the intermittent pulse during discharge of $\mathrm{Li} / \mathrm{Ag}_{7} \mathrm{Fe}_{3}\left(\mathrm{P}_{2} \mathrm{O}_{7}\right)_{4}$ cell is conducted at $10 \mathrm{~mA} / \mathrm{cm}^{2}$ current density for two seconds of each pulse. Figure 11(a) shows the discharge curve including 12 intermittent pulses and the inset graph shows the shape of pulse 6 to illustrate the voltages that were used in the calculation of Ohmic resistance.

The changes in Ohmic resistance are shown in Figure 11(b) along with the discharge curve and Ag metal formation from operando study. In early discharge (before 2.5ee), a rapid decrease in Ohmic resistance is observed, consistent with the rapid Ag metal formation. At 4.8ee reduction, the resistance decreased by $62 \%$ (from $65 \mathrm{Ohm}$ to $25 \mathrm{Ohm}$ ) and reached its minimum value. The resistance stays the same at $34 \mathrm{Ohm}$ after 7ee reduction, indicating that additional Ag metal formation later in the discharge process does not result in a further decrease in cell resistance. 

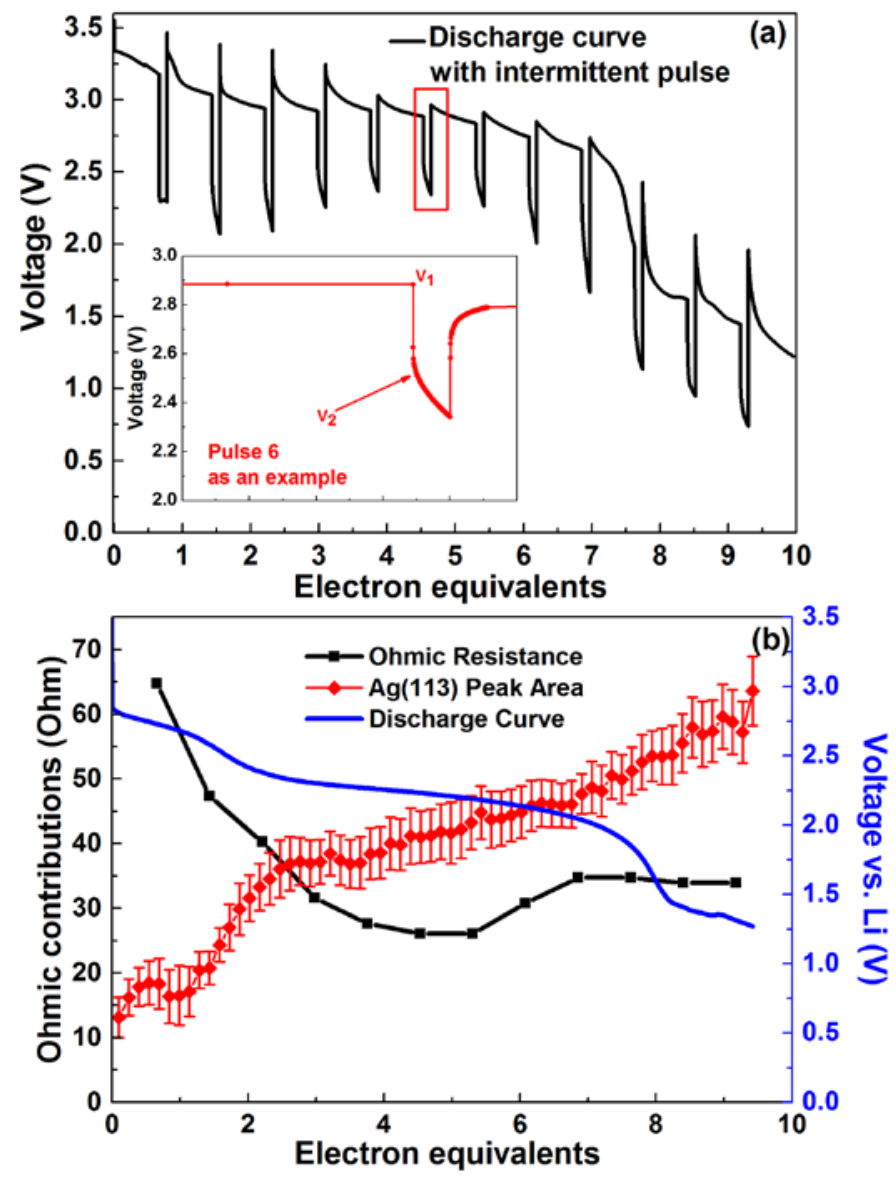

Figure 11. (a) Intermittent pulse discharge curve, voltage response at pulse 6 shown in inset; (b) Overall Ohmic contributions from the pulse test in $\mathrm{Li} / \mathrm{Ag}_{7} \mathrm{Fe}_{3}\left(\mathrm{P}_{2} \mathrm{O}_{7}\right)_{4}$ cell.

\section{CONCLUSIONS}

We studied the Ag metal formation upon the discharge of an $\mathrm{Li} / \mathrm{Ag}_{7} \mathrm{Fe}_{3}\left(\mathrm{P}_{2} \mathrm{O}_{7}\right)_{4}$ cell using several techniques, including AC impedance spectroscopy, ex-situ XRD, ex-situ SEM, and operando XRD from a synchrotron source. The charge transfer resistance $\left(\mathrm{R}_{\mathrm{ct}}\right)$ decreased from 41 to 33 Ohm (19\% reduction) as early as 0.1ee discharge and remained low at 25 Ohm at 1ee and 2ee discharge. Ex-situ XRD showed the presence of Ag metal after the first CV reduction peak with continued formation of additional $\mathrm{Ag}^{0}$ until the end of discharge. SEM images of electrodes 
reduced by 7.7 ee showed smaller size features of Ag metal and shorter nearest neighbor distances compared with those of an electrode reduced by 3.6 ee. Specifically, all these results were consistent with the operando study which showed the onset of $\mathrm{Ag}^{+}$ion reduction preferentially occurred upon the initial discharge up to 3 ee, followed by a majority of $\mathrm{Fe}^{3+}$ reduction concurrent with the $\mathrm{Ag}^{+}$ions reduction in the later stages of reduction. The remainder of the $\mathrm{Ag}^{+}$ions reduction occurred in the final stages of discharge beyond 7 ee. $\mathrm{The}^{\text {initial }} \mathrm{Ag}^{+}$ ion reductions are proposed to be from $\mathrm{Ag}(4)$ structural sites which intersect locations along the ion diffusion path. Finally, a pulse test was conducted to investigate the effect of $\mathrm{Ag}^{0}$ formation on electrochemical performance. The Ohmic resistance decreased by $62 \%$ and reached a minimum of $26 \mathrm{Ohm}$ at 4.8 ee reduction. It remained at $34 \mathrm{Ohm}$ after 7 ee reduction illustrating that the formation of additional silver nanoparticles did not further decrease the cell resistance once a sufficient conductive network was established.

\section{Corresponding Authors}

*Email: amy.marschilok@stonybrook.edu (ACM)

*Email: esther.takeuchi@stonybrook.edu (EST)

*Email: kenneth.takeuchi.1@stonybrook.edu (KJT)

\section{ACKNOWLEDGMENTS}

This work was supported as part of the Center for Mesoscale Transport Properties, an Energy Frontier Research Center supported by the U.S. Department of Energy, Office of Science, Basic Energy Sciences, under award \#DE-SC0012673. Use of the beamline 6-ID-D at the Advanced Photon Source at Argonne National Laboratory, was supported by the US Department of Energy, Office of Basic Energy Sciences, under Contract No. DE-AC02-06CH11357. K. Kirshenbaum 
acknowledges postdoctoral support from Brookhaven National Laboratory and the Gertrude and Maurice Goldhaber Distinguished Fellowship Program. The authors would like to thank J. Sinsheimer from Brookhaven National Lab and D. Robinson from APS/ANL for their help with operando experimental setup and data analysis.

\section{REFERENCES}

(1) Tamaru, M.; Chung, S. C.; Shimizu, D.; Nishimura, S. I.; Yamada, A. Pyrophosphate Chemistry Toward Safe Rechargeable Batteries. Chem. Mater. 2013, 25, 2538-2543.

(2) Padhi, A. K.; Nanjundaswamy, K. S.; Goodenough, J. B. Phospho-Olivines as PositiveElectrode Materials for Rechargeable Lithium Batteries. J. Electrochem. Soc. 1997, 144, 11881194.

(3) Kim, H.; Shakoor, R. A.; Park, C.; Lim, S. Y.; Kim, J. S.; Jo, Y. N.; Cho, W.; Miyasaka, K.; Kahraman, R.; Jung, Y.; et al. $\mathrm{Na}_{2} \mathrm{FeP}_{2} \mathrm{O}_{7}$ as a Promising Iron-Based Pyrophosphate Cathode for Sodium Rechargeable Batteries: A Combined Experimental and Theoretical Study. Adv. Func. Mater. 2013, 23, 1147-1155.

(4) Zhou, H.; Upreti, S.; Chernova, N. A.; Hautier, G.; Ceder, G.; Whittingham, M. S. Iron and Manganese Pyrophosphates as Cathodes for Lithium-Ion Batteries. Chem. Mater. 2011, 23, 293300.

(5) Nishimura, S.; Nakamura, M.; Natsui, R.; Yamada, A. New Lithium Iron Pyrophosphate as 3.5 V Class Cathode Material for Lithium Ion Battery. J. Am. Chem. Soc. 2010, 132, 1359613597.

(6) Kim, H.; Lee, S.; Park, Y. U.; Kim, H.; Kim, J.; Jeon, S.; Kang, K. Neutron and X-Ray Diffraction Study of Pyrophosphate-Based $\mathrm{Li}_{2-\mathrm{x}} \mathrm{MP}_{2} \mathrm{O}_{7}(\mathrm{M}=\mathrm{Fe}, \mathrm{Co})$ for Lithium Rechargeable Battery Electrodes. Chem. Mater. 2011, 23, 3930-3937. 
(7) Shakoor, R. A.; Kim, H.; Cho, W.; Lim, S. Y.; Song, H.; Lee, J. W.; Kang, J. K.; Kim, Y. T.;

Jung, Y.; Choi, J. W. Site-Specific Transition Metal Occupation in Multicomponent

Pyrophosphate for Improved Electrochemical and Thermal Properties in Lithium Battery

Cathodes: A Combined Experimental and Theoretical Study. J. Am. Chem. Soc. 2012, 134, $11740-11748$.

(8) Manthiram, A.; Goodenough, J. B. Lithium Insertion into $\mathrm{Fe}_{2}\left(\mathrm{SO}_{4}\right)_{3}$ Frameworks. J. Power Sources 1989, 26, 403-408.

(9) Nytén, A.; Abouimrane, A.; Armand, M.; Gustafsson, T.; Thomas, J. O. Electrochemical Performance of $\mathrm{Li}_{2} \mathrm{FeSiO}_{4}$ as a New Li-Battery Cathode Material. Electrochem. Commun. 2005, 7, 156-160.

(10) Barker, J.; Saidi, M. Y.; Swoyer, J. L. Electrochemical Insertion Properties of the Novel Lithium Vanadium Fluorophosphate, $\mathrm{LiVPO}_{4} \mathrm{~F}$. J. Electrochem. Soc. 2003, 150, A1394-A1398. (11) Chung, S. Y.; Bloking, J. T.; Chiang, Y. M. Electronically Conductive Phospho-Olivines as Lithium Storage Electrodes. Nat. Mater. 2002, 1, 123-128.

(12) Huang, H.; Yin, S. C.; Nazar, L. F. Approaching Theoretical Capacity of $\mathrm{LiFePO}_{4}$ at Room Temperature at High Rates. Electrochem. Solid State Lett. 2001, 4, A170-A172.

(13) Kim, D. H.; Kim, J. Synthesis of $\mathrm{LiFePO}_{4}$ Nanoparticles in Polyol Medium and Their Electrochemical Properties. Electrochem. Solid State Lett. 2006, 9, A439-A442.

(14) Padhi, A. K.; Nanjundaswamy, K. S.; Masquelier, C.; Okada, S.; Goodenough, J. B. Effect of Structure on the $\mathrm{Fe}^{3+} / \mathrm{Fe}^{2+}$ Redox Couple in Iron Phosphates. J. Electrochem. Soc. 1997, 144, 1609-1613. 
(15) Barpanda, P.; Liu, G.; Ling, C. D.; Tamaru, M.; Avdeev, M.; Chung, S. C.; Yamada, Y.;

Yamada, A. $\mathrm{Na}_{2} \mathrm{FeP}_{2} \mathrm{O}_{7}$ : A Safe Cathode for Rechargeable Sodium-Ion Batteries. Chem. Mater.

2013, 25, 3480-3487.

(16) Clark, J. M.; Barpanda, P.; Yamada, A.; Islam, M. S. Sodium-Ion Battery Cathodes

$\mathrm{Na}_{2} \mathrm{FeP}_{2} \mathrm{O}_{7}$ and $\mathrm{Na}_{2} \mathrm{MnP}_{2} \mathrm{O}_{7}$ : Diffusion Behaviour for High Rate Performance. J. Mater. Chem. A 2014, 2, 11807-11812.

(17) Kim, J.; Lee, B.; Kim, H.; Kim, H.; Kang, K. Redesign of $\mathrm{Li}_{2} \mathrm{MP}_{2} \mathrm{O}_{7}(\mathrm{M}=\mathrm{Fe}$ or $\mathrm{Mn}$ ) by

Tuning the Li Diffusion in Rechargeable Battery Electrodes. Chem. Mater. 2016, 28, 6894-6899.

(18) Kim, H.; Park, C. S.; Choi, J. W.; Jung, Y. Tuning the Phase Stability of Sodium Metal Pyrophosphates for Synthesis of High Voltage Cathode Materials. Chem. Mater. 2016, 28, 67246730.

(19) Quarez, E.; Mentre, O.; Oumellal, Y.; Masquelier, C. Crystal Structures of New Silver Ion Conductors $\mathrm{Ag}_{7} \mathrm{Fe}_{3}\left(\mathrm{X}_{2} \mathrm{O}_{7}\right)_{4}(\mathrm{X}=\mathrm{P}, \mathrm{As})$. New J. Chem. 2009, 33, 998-1005.

(20) Marschilok, A. C.; Takeuchi, K. J.; Takeuchi, E. S. Preparation and Electrochemistry of Silver Vanadium Phosphorous Oxide, $\mathrm{Ag}_{2} \mathrm{VO}_{2} \mathrm{PO}_{4}$. Electrochem. Solid State Lett. 2009, 12, A5A9.

(21) Takeuchi, E. S.; Marschilok, A. C.; Tanzil, K.; Kozarsky, E. S.; Zhu, S.; Takeuchi, K. J. Electrochemical Reduction of Silver Vanadium Phosphorus Oxide, $\mathrm{Ag}_{2} \mathrm{VO}_{2} \mathrm{PO}_{4}$ : The Formation of Electrically Conductive Metallic Silver Nanoparticles. Chem. Mater. 2009, 21, 4934-4939. (22) Marschilok, A. C.; Kozarsky, E. S.; Tanzil, K.; Zhu, S.; Takeuchi, K. J.; Takeuchi, E. S. Electrochemical Reduction of Silver Vanadium Phosphorous Oxide, $\mathrm{Ag}_{2} \mathrm{VO}_{2} \mathrm{PO}_{4}$ : Silver Metal Deposition and Associated Increase in Electrical Conductivity. J. Power Sources 2010, 195, 6839-6846. 
(23) Kim, Y. J.; Lee, C. Y.; Marschilok, A. C.; Takeuchi, K. J.; Takeuchi, E. S. Ag VOPO$_{4}$ : A Demonstration of the Dependence of Battery-Related Electrochemical Properties of Silver Vanadium Phosphorous Oxides on Ag/V Ratios. J. Power Sources 2011, 196, 3325-3330. (24) Marschilok, A. C.; Kim, Y. J.; Takeuchi, K. J.; Takeuchi, E. S. Silver Vanadium Phosphorous Oxide, $\mathrm{Ag}_{0.48} \mathrm{VO}_{2} \mathrm{PO}_{4}$ : Exploration as a Cathode Material in Primary and Secondary Battery Applications. J. Electrochem. Soc. 2012, 159, A1690-A1695.

(25) Takeuchi, E. S.; Lee, C. Y.; Cheng, P. J.; Menard, M. C.; Marschilok, A. C.; Takeuchi, K. J. Silver Vanadium Diphosphate $\mathrm{Ag}_{2} \mathrm{VP}_{2} \mathrm{O}_{8}$ : Electrochemistry and Characterization of Reduced Material Providing Mechanistic Insights. J. Solid State Chem. 2013, 200, 232-240.

(26) Zhou, J.; Liang, Q.; Pan, A. Q.; Zhang, X. L.; Zhu, Q. Y.; Liang, S. Q.; Cao, G. Z. The General Synthesis of Ag Nanoparticles Anchored on Silver Vanadium Oxides: Towards High Performance Cathodes for Lithium-Ion Batteries. J. Mater. Chem. A 2014, 2, 11029-11034. (27) Leifer, N. D.; Colon, A.; Martocci, K.; Greenbaum, S. G.; Alamgir, F. M.; Reddy, T. B.; Gleason, N. R.; Leising, R. A.; Takeuchi, E. S. Nuclear Magnetic Resonance and X-Ray Absorption Spectroscopic Studies of Lithium Insertion in Silver Vanadium Oxide Cathodes. J. Electrochem. Soc. 2007, 154, A500-A506.

(28) Takeuchi, K. J.; Leising, R. A.; Palazzo, M. J.; Marschilok, A. C.; Takeuchi, E. S. Advanced Lithium Batteries for Implantable Medical Devices: Mechanistic Study of SVO Cathode Synthesis. J. Power Sources 2003, 119, 973-978.

(29) Albrecht, T. A.; Sauvage, F.; Bodenez, V.; Tarascon, J. M.; Poeppelmeier, K. R. Room Temperature Synthesis of the Larger Power, High Silver Density Cathode Material $\mathrm{Ag}_{4} \mathrm{~V}_{2} \mathrm{O}_{6} \mathrm{~F}_{2}$ for Implantable Cardioverter Defibrillators. Chem. Mater. 2009, 21, 3017-3020. 
(30) Hu, W.; Zhang, X. B.; Cheng, Y. L.; Wu, C. Y.; Cao, F.; Wang, L. M. Mild and CostEffective One-Pot Synthesis of Pure Single-Crystalline Beta- $\mathrm{Ag}_{0.33} \mathrm{~V}_{2} \mathrm{O}_{5}$ Nanowires for Rechargeable Li-Ion Batteries. ChemSusChem 2011, 4, 1091-1094.

(31) Kirshenbaum, K. C.; Bock, D. C.; Brady, A. B.; Marschilok, A. C.; Takeuchi, K. J.; Takeuchi, E. S. Electrochemical Reduction of an $\mathrm{Ag}_{2} \mathrm{VO}_{2} \mathrm{PO}_{4}$ Particle: Dramatic Increase of Local Electronic Conductivity. Phys. Chem. Chem. Phys. 2015, 17, 11204-11210.

(32) Zhang, Y.; Kirshenbaum, K. C.; Marschilok, A. C.; Takeuchi, E. S.; Takeuchi, K. J. Battery Relevant Electrochemistry of $\mathrm{Ag}_{7} \mathrm{Fe}_{3}\left(\mathrm{P}_{2} \mathrm{O}_{7}\right)_{4}$ : Contrasting Contributions from the Redox Chemistries of $\mathrm{Ag}^{+}$and $\mathrm{Fe}^{3+}$. Chem. Mater. 2016, 28, 7619-7628.

(33) Walus, S.; Barchasz, C.; Colin, J. F.; Martin, J. F.; Elkaim, E.; Lepretre, J. C.; Alloin, F. New Insight into the Working Mechanism of Lithium-Sulfur Batteries: In Situ and Operando XRay Diffraction Characterization. Chem. Commun. 2013, 49, 7899-7901.

(34) Cañas, N. A.; Wolf, S.; Wagner, N.; Friedrich, K. A. In-Situ X-Ray Diffraction Studies of Lithiumesulfur Batteries. J. Power Sources 2013, 226, 313-319.

(35) Nelson, J.; Misra, S.; Yang, Y.; Jackson, A.; Liu, Y.; Wang, H.; Dai, H.; Andrews, J. C.; Cui, Y.; Toney, M. F. In Operando X-Ray Diffraction and Transmission X-Ray Microscopy of Lithium Sulfur Batteries. J. Am. Chem. Soc. 2012, 134, 6337-6343.

(36) Pinedo, R.; Weber, D. A.; Bergner, B.; Schroder, D.; Adelhelm, P.; Janek, J. Insights into the Chemical Nature and Formation Mechanisms of Discharge Products in Na- $\mathrm{O}_{2}$ Batteries by Means of Operando X-Ray Diffraction. J. Phys. Chem. C 2016, 120, 8472-8481.

(37) Liu, Q.; He, H.; Li, Z. F.; Liu, Y. D.; Ren, Y.; Lu, W. Q.; Lu, J.; Stach, E. A.; Xie, J. RateDependent, Li-Ion Insertion/Deinsertion Behavior of $\mathrm{LiFePO}_{4}$ Cathodes in Commercial 18650 $\mathrm{LiFePO}_{4}$ Cells. ACS Appl. Mater. Inter. 2014, 6, 3282-3289. 
(38) Orikasa, Y.; Maeda, T.; Koyama, Y.; Murayama, H.; Fukuda, K.; Tanida, H.; Arai, H.;

Matsubara, E.; Uchimoto, Y.; Ogumi, Z. Direct Observation of a Metastable Crystal Phase of $\mathrm{Li}_{\mathrm{x}} \mathrm{FePO}_{4}$ under Electrochemical Phase Transition. J. Am. Chem. Soc. 2013, 135, 5497-5500.

(39) Takahashi, I.; Mori, T.; Yoshinari, T.; Orikasa, Y.; Koyama, Y.; Murayama, H.; Fukuda, K.; Hatano, M.; Arai, H.; Uchimoto, Y.; et al. Irreversible Phase Transition between $\mathrm{LiFePO}_{4}$ and $\mathrm{FePO}_{4}$ During High-Rate Charge-Discharge Reaction by Operando X-Ray Diffraction. J. Power Sources 2016, 309, 122-126.

(40) Siddique, N. A.; Salehi, A.; Wei, Z.; Liu, D.; Sajjad, S. D.; Liu, F. Q. Length-ScaleDependent Phase Transformation of $\mathrm{LiFePO}_{4}$ : An in Situ and Operando Study Using MicroRaman Spectroscopy and XRD. ChemPhysChem 2015, 16, 2383-2388.

(41) Lowe, M. A.; Gao, J.; Abruna, H. D. In Operando X-Ray Studies of the Conversion Reaction in $\mathrm{Mn}_{3} \mathrm{O}_{4}$ Lithium Battery Anodes. J. Mater. Chem. A 2013, 1, 2094-2103. (42) Permien, S.; Indris, S.; Schurmann, U.; Kienle, L.; Zander, S.; Doyle, S.; Bensch, W. What Happens Structurally and Electronically During the Li Conversion Reaction of $\mathrm{CoFe}_{2} \mathrm{O}_{4}$ Nanoparticles: An Operando XAS and XRD Investigation. Chem. Mater. 2016, 28, 434-444. (43) Permien, S.; Indris, S.; Neubuser, G.; Fiedler, A.; Kienle, L.; Zander, S.; Doyle, S.; Richter, B.; Bensch, W. The Role of Reduced Graphite Oxide in Transition Metal Oxide Nanocomposites Used as Li Anode Material: An Operando Study on $\mathrm{CoFe}_{2} \mathrm{O}_{4} / \mathrm{RGO}$. Chem. Eur. J. 2016, 22, 16927-16936.

(44) Fehse, M.; Monconduit, L.; Fischer, F.; Tessier, C.; Stievano, L. Study of the Insertion Mechanism of Lithium into Anatase by Operando X-Ray Diffraction and Absorption Spectroscopy. Solid State Ionics 2014, 268, 252-255. 
(45) Fehse, M.; Ben Yahia, M.; Monconduit, L.; Lemoigno, F.; Doublet, M. L.; Fischer, F.;

Tessier, C.; Stievano, L. New Insights on the Reversible Lithiation Mechanism of $\mathrm{TiO}_{2}(\mathrm{~B})$ by Operando X-Ray Absorption Spectroscopy and X-Ray Diffraction Assisted by First-Principles Calculations. J. Phys. Chem. C 2014, 118, 27210-27218.

(46) Moser, F.; Fourgeot, F.; Rouget, R.; Crosnier, O.; Brousse, T. In Situ X-Ray Diffraction Investigation of Zinc Based Electrode in Ni-Zn Secondary Batteries. Electrochim. Acta 2013, 109, 110-116.

(47) Lim, L. Y.; Fan, S. F.; Hng, H. H.; Toney, M. F. Operando X-Ray Studies of Crystalline Ge Anodes with Different Conductive Additives. J. Phys. Chem. C 2015, 119, 22772-22777.

(48) Bleith, P.; Kaiser, H.; Novak, P.; Villevieille, C. In Situ X-Ray Diffraction Characterisation of $\mathrm{Fe}_{0.5} \mathrm{TiOPO}_{4}$ and $\mathrm{Cu}_{0.5} \mathrm{TiOPO}_{4}$ as Electrode Material for Sodium-Ion Batteries. Electrochim. Acta 2015, 176, 18-21.

(49) Takeuchi, E. S.; Marschilok, A. C.; Takeuchi, K. J.; Ignatov, A.; Zhong, Z.; Croft, M., Energy Dispersive X-Ray Diffraction of Lithium-Silver Vanadium Phosphorous Oxide Cells: In Situ Cathode Depth Profiling of an Electrochemical Reduction-Displacement Reaction. Energy Environ. Sci. 2013, 6, 1465-1470.

(50) Kirshenbaum, K. C.; Bock, D. C.; Zhong, Z.; Marschilok, A. C.; Takeuchi, K. J.; Takeuchi, E. S. In Situ Profiling of Lithium/ $\mathrm{Ag}_{2} \mathrm{VP}_{2} \mathrm{O}_{8}$ Primary Batteries Using Energy Dispersive X-Ray Diffraction. Phys. Chem. Chem. Phys. 2014, 16, 9138-9147.

(51) Kirshenbaum, K.; Bock, D. C.; Lee, C. Y.; Zhong, Z.; Takeuchi, K. J.; Marschilok, A. C.;

Takeuchi, E. S. In Situ Visualization of $\mathrm{Li} / \mathrm{Ag}_{2} \mathrm{VP}_{2} \mathrm{O}_{8}$ Batteries Revealing Rate-Dependent Discharge Mechanism. Science 2015, 347, 149-154. 
(52) Masquelier, C.; Dyvoire, F.; Rodier, N. Crytal Structure of the Sodium Ion Conductor Alpha- $\mathrm{Na}_{7} \mathrm{Fe}_{3}\left(\mathrm{P}_{2} \mathrm{O}_{7}\right)_{4}$---- Evidence for a Long Range Ordering of the $\mathrm{Na}^{+}$Ions. J. Solid State Chem. 1991, 95, 156-167.

(53) Masquelier, C.; Dyvoire, F.; Bretey, E.; Berthet, P.; Peytourchansac, C. A New Family of Sodium-Ion Conductors - the Diphosphates and Diarsenates $\mathrm{Na}_{7} \mathrm{M}_{3}\left(\mathrm{X}_{2} \mathrm{O}_{7}\right)_{4}(\mathrm{M}=\mathrm{Al}, \mathrm{Ga}, \mathrm{Cr}, \mathrm{Fe}$, $\mathrm{X}=\mathrm{P}, \mathrm{As})$. Solid State Ionics 1994, 67, 183-189.

(54) Schneider, C. A.; Rasband, W. S.; Eliceiri, K. W. Nih Image to ImageJ: 25 Years of Image Analysis. Nat. Methods 2012, 9, 671-675.

(55) Johnson, D. Zview and Zplot: A Software Program for Ies Analysis, Version 2.8. Scribner Associates, Inc., Southern Pines, NC 2002.

(56) Mhin, S.; Nittala, K.; Cozzan, C.; Kim, K.; Robinson, D. S.; Sanchez, L. M.; Polcawich, R. G.; Jones, J. L. Role of the $\mathrm{PbTiO}_{3}$ Seed Layer on the Crystallization Behavior of PZT Thin Films. J. Am. Ceram. Soc. 2015, 98, 1407-1412.

(57) Shui, J. L.; Okasinski, J. S.; Chen, C.; Almer, J. D.; Liu, D. J. In Operando Spatiotemporal Study of $\mathrm{Li}_{2} \mathrm{O}_{2}$ Grain Growth and Its Distribution Inside Operating $\mathrm{Li}-\mathrm{O}_{2}$ Batteries. ChemSusChem 2014, 7, 543-548.

(58) Hammersley, A. P. Fit2D Ver. 12.077 Reference Manual ESRF98HA01T, 12.077, European Synchrotron Radiation Facility: 2009.

(59) PeakFit Ver. 4.12. Seasolve Software Inc.: Framingham, MA, 2003.

(60) Momma, T.; Matsunaga, M.; Mukoyama, D.; Osaka, T. AC Impedance Analysis of Lithium Ion Battery Under Temperature Control. J. Power Sources 2012, 216, 304-307.

(61) Dudney, N. J.; Li, J. Using All Energy in a Battery. Science 2015, 347, 131-132. 
(62) Saheb, N.; Qadir, N.; Siddiqui, M.; Arif, A.; Akhtar, S.; Al-Aqeeli, N. Characterization of Nanoreinforcement Dispersion in Inorganic Nanocomposites: A Review. Materials 2014, 7, 4148-4181. 


\section{TOC Graphic}

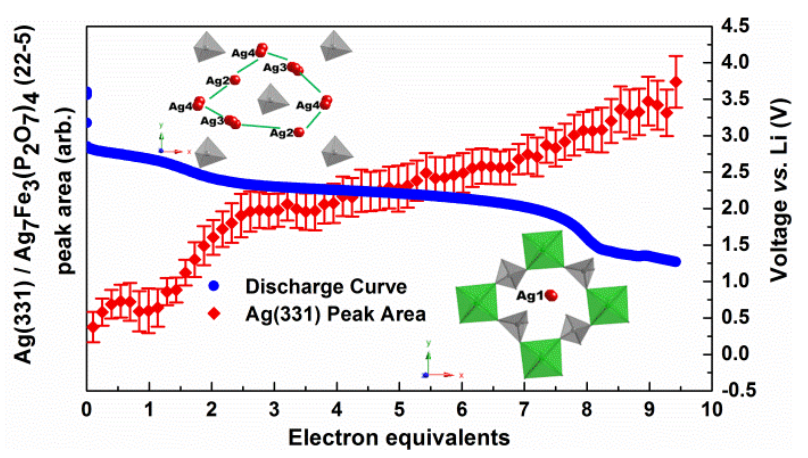

